\title{
Formation waters from Mississippian-Pennsylvanian reservoirs, Illinois basin, USA: Chemical and isotopic constraints on evolution and migration
}

\author{
Alan M. Stueber, ${ }^{1}$ Lynn M. Walter, ${ }^{2}$ Ted J. Huston, ${ }^{2}$ and Paul PUShKaR ${ }^{3}$ \\ 'Department of Geography and Earth Science, Southern Illinois University, Edwardsville, IL 62026, USA \\ ${ }^{2}$ Department of Geological Sciences, University of Michigan, Ann Arbor, MI 48109, USA \\ ${ }^{3}$ Department of Geological Sciences, Wright State University, Dayton, OH 45435, USA
}

(Received December 27, 1991; accepted in revised form August 4, 1992)

\begin{abstract}
We have analyzed a suite of seventy-four formation-water samples from Mississippian and Pennsylvanian carbonate and siliciclastic strata in the Illinois basin for major, minor, and trace element concentrations and for strontium isotopic composition. A subset of these samples was also analyzed for boron isotopic composition. Data are used to interpret origin of salinity and chemical and $\mathrm{Sr}$ isotopic evolution of the brines and in comparison with a similar data set from an earlier study of basin formation waters from Silurian-Devonian reservoirs. Systematics of $\mathrm{Cl}-\mathrm{Br}-\mathrm{Na}$ show that present Mississippian-Pennsylvanian brine salinity can be explained by a combination of subaerial seawater evaporation short of halite saturation and subsurface dissolution of halite from an evaporite zone in the middle Mississippian St. Louis Limestone, along with extensive dilution by mixing with meteoric waters. Additional diagenetic modifications in the subsurface interpreted from cation / $\mathrm{Br}$ ratios include $\mathrm{K}$ depletion through interaction with clay minerals, $\mathrm{Ca}$ enrichment, and $\mathrm{Mg}$ depletion by dolomitization, and $\mathrm{Sr}$ enrichment through $\mathrm{CaCO}_{3}$ recrystallization and dolomitization. Ste. Genevieve Limestone (middle Mississippian) formation waters show ${ }^{87} \mathrm{Sr} /{ }^{86} \mathrm{Sr}$ ratios in the range $0.70782-0.70900$, whereas waters from the siliciclastic reservoirs are in the range $0.70900-0.71052$. Inverse correlations between ${ }^{87} \mathrm{Sr} /{ }^{86} \mathrm{Sr}$ and $\mathrm{B}, \mathrm{Li}$, and $\mathrm{Mg}$ concentrations suggest that the brines acquired radiogenic ${ }^{87} \mathrm{Sr}$ through interaction with siliciclastic minerals. Completely unsystematic relations between ${ }^{87} \mathrm{Sr} /{ }^{86} \mathrm{Sr}$ and $1 / \mathrm{Sr}$ are observed; $\mathrm{Sr}$ concentrations in Ste. Genevieve and Aux Vases (middle Mississippian) waters appear to be buffered by equilibrium with respect to $\mathrm{SrSO}_{4}$. Although there are many similarities in their origin and evolution, these formation waters are distinguished from Silurian-Devonian brines in the basin by elevated $\mathrm{Cl} / \mathrm{Br}$ and $\mathrm{Na} / \mathrm{Br}$ ratios and by unsystematic $\mathrm{Sr}$ isotope relationships. Thus waters from these two major segments of the Illinois basin stratigraphic column form distinct geochemical regimes which are separated by the New Albany Shale Group (DevonianMississippian) regional aquitard. Geochemical evolution appears to have been influenced significantly by Paleozoic and Mesozoic hydrologic flow systems in the basin.
\end{abstract}

\section{INTRODUCTION}

THE ORIGIN AND CHEMICAL evolution of formation waters in sedimentary basins are topics of considerable current debate. Specific questions involve the origin of fluid salinity, the importance of local water-rock interactions, the pathways of fluid migration, and the timing of migration. Recently, STUEBER and WALTER (1991) used Cl-Br relations to show that brine compositions from Silurian-Devonian strata in the Illinois basin are consistent with seawater evaporation short of halitc precipitation; Sr isotope data and $\delta \mathrm{D}-\delta^{18} \mathrm{O}$ relations indicated that present Silurian-Devonian formation waters represent 3-component mixtures involving remnant evaporated Silurian-Devonian seawater, ${ }^{87} \mathrm{Sr}$-enriched fluid that probably migrated from stratigraphically adjacent New Albany shales, and a major component of meteoric water. Systematic Cl-Br-Na relations in waters from Ordovician through Pennsylvanian reservoirs led WALTER et al. (1990) to conclude that the overall $\mathrm{Cl}$ budget of Illinois basin formation waters has been more significantly influenced by retention of subaerially evaporated seawater than by halite dissolution. Characteristic differences in both Cl-Br-Na relations (WALTER et al., 1990) and strontium isotope systematics (STUEBER et al., 1987) between formation waters from Ordovician through Devonian strata and those from Mississippian and
Pennsylvanian reservoirs suggest the existence of two chemically and isotopically distinct fluid regimes, in which the waters migrated and evolved in different ways. The two segments of the stratigraphic section are separated by the New Albany Shale Group, which forms a regional aquitard (BETHKE et al., 1991).

Knowledge of fluid origin and migration in the Illinois basin has increased significantly in recent years. HATCH et al. (1991) carried out organic geochemical studies which demonstrated that New Albany Group shales were the source rocks for over $99 \%$ of oil produced in the basin. Through Lopatin modeling CLUFF and BYRNES (1991) deduced that this oil was generated for the most part between 300 and 150 $\mathrm{Ma}$, coincident with development of many structures in the basin. BETHKE et al. (1991) used organic geochemical correlations of source rock and reservoir oils along with quantitative models of basin paleohydrology to show that some New Albany oil, as part of a regional gravity-driven flow system, had migrated more than $100 \mathrm{~km}$ from areas of intense generation near the basin's depocenter to Silurian reservoirs in the north and northwest. Through paleohydrologic modeling BETHKE (1986) has also suggested that ore deposits of the Upper Mississippi Valley district formed from Illinois basin brines during a period of regional groundwater flow across the hasin, initiated by uplift of the Pascola arch on the 
southern margin in post-Early Permian through pre-Late Cretaceous time.

In this study, we report analyses of major, minor, and trace elements and strontium isotopes in seventy-four formationwater samples from Mississippian and Pennsylvanian carbonate and siliciclastic reservoir rocks in the Illinois basin, a data set which generally parallels that presented earlier for Silurian-Devonian waters (STUEBER and WALTER, 1991). We also report boron isotope analyses for a subset of samples from all of these reservoirs. We interpret the origin and chemical and isotopic evolution of the Mississippian-Pennsylvanian brines, while drawing a comparison with the origin and evolution of Silurian-Devonian brines in terms of the controls exerted by subaerial evaporation, water-rock interaction, and fluid mixing. The apparent influence of paleohydrologic flow patterns and the important role of the New Albany Shale Group in producing two contrasting geochemical formation-water regimes are emphasized.

\section{ILLINOIS BASIN FORMATION WATERS}

The Illinois intracratonic basin, located in Illinois, western Kentucky, and southwestern Indiana (Fig. 1), began as a rift basin during Early and Middle Cambrian time and evolved into a cratonic embayment which subsided from Late Cambrian into Permian time (KolATA and NELSON, 1991). The succession of Paleozoic marine carbonate and siliciclastic rocks that accumulated has a maximum present thickness of about $4 \mathrm{~km}$ in southern Illinois and about $7 \mathrm{~km}$ in western Kentucky. Uplift of the Pascola arch on the southern margin of the embayment resulted in basin closure sometime between late Paleozoic and late Mesozoic time. The Cambrian and Ordovician sedimentary rocks (Fig. 1) are primarily carbonates and mature quartzarenites; Silurian through middle Mississippian (Valmeyeran) sedimentary rocks are almost entirely carbonates. Cyclic, interbedded sandstones, shales, and limestones characterize upper Mississippian (Chesterian) and Pennsylvanian strata. The pre-Chesterian section is generally deficient in shale, with the exception of the Ordovician Maquoketa and Devonian-Mississippian New Albany shale groups which form regional aquitards (BETHKE et al., 1991). Nearly all Permian rocks have been removed by erosion. Bedded salt deposits are unknown in the stratigraphic section, but minor amounts of anhydrite occur in some Ordovician and Valmeyeran carbonate strata and several carbonate units contain facies with evidence of deposition under restricted conditions.

Most formation waters in Illinois basin strata are $\mathrm{Na}-\mathrm{Ca}$ $\mathrm{Cl}$ brines which are slightly depleted in $\mathrm{Na}$, strongly depleted in $\mathrm{K}, \mathrm{Mg}$, and $\mathrm{SO}_{4}$, and noticeably enriched in $\mathrm{Ca}$ relative to seawater (HANOR, 1979; STUEBER and WALTER, 1991). Total dissolved solids in water from a particular formation increase downdip toward the center of the basin (MEENTS et al., 1952). For this study, we collected formation-water samples from reservoirs in sixty-four producing oil fields within the state of Illinois (Fig. 1; Table 1). None of these fields had been subjected to waterflood operations for enhanced petroleum recovery prior to sample collection. The water samples were produced from nine Mississippian and Pennsylvanian carbonate and siliciclastic reservoirs (Fig. 2; Table 1), which
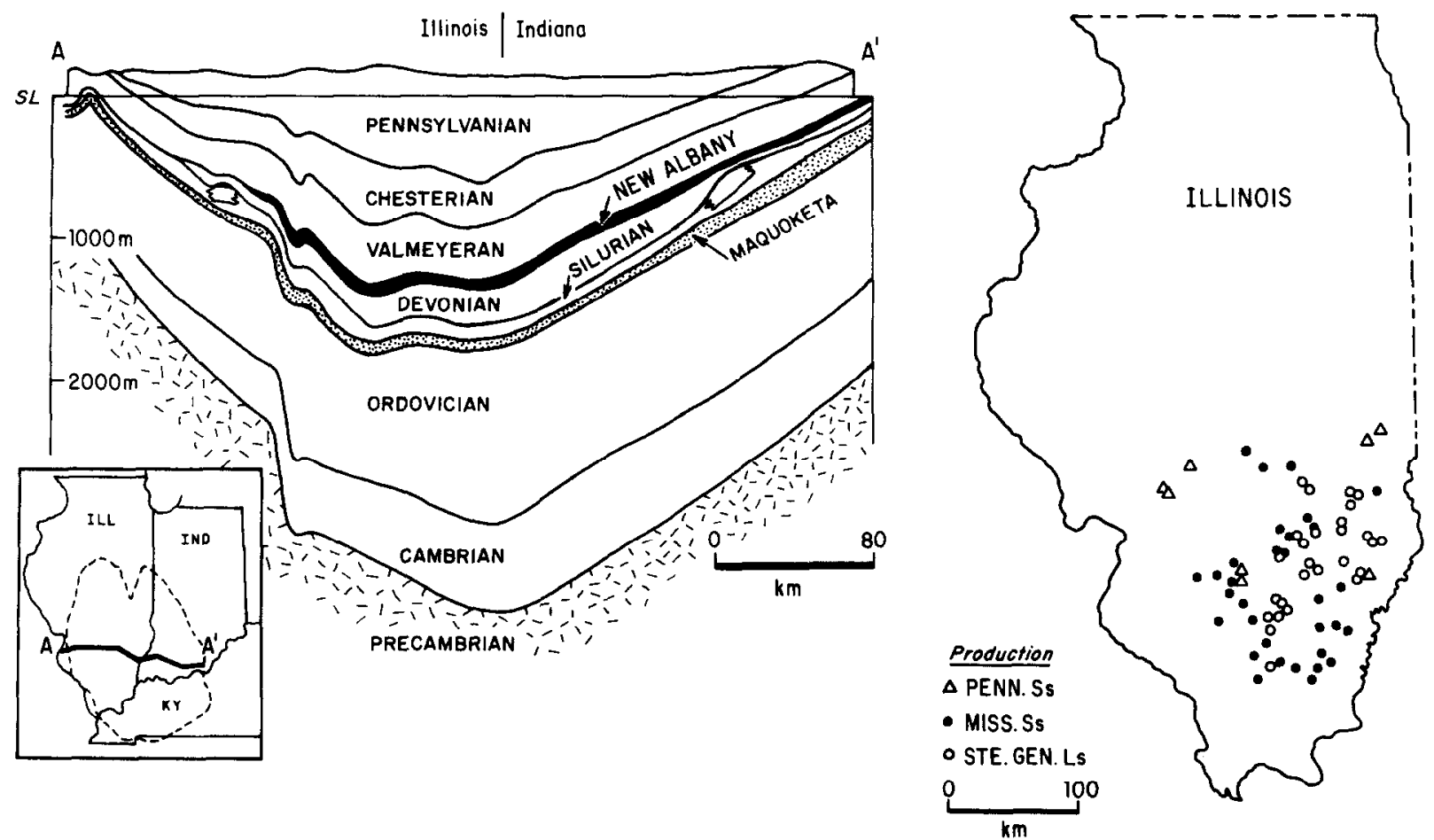

FIG. 1. The Illinois basin (inset) in the mid-continent region of the USA, an east-west subsurface cross-section, and locations of oil fields from which formation-water samples were collected. The Valmeyeran Series is middle Mississippian and the Chesterian Series is upper Mississippian. Modified from SWANN (1967). 


\begin{tabular}{|c|c|c|c|c|}
\hline $\begin{array}{l}\text { Sample } \\
\text { number }\end{array}$ & $\begin{array}{c}\text { Reservoir } \\
\text { _ock }\end{array}$ & Field & $\begin{array}{c}\text { Fetd } \\
\text { production } \\
\text { deposth (m) }\end{array}$ & $\begin{array}{c}\text { Salinity } \\
(01)\end{array}$ \\
\hline \multicolumn{5}{|c|}{ PENNSYLVANIAN } \\
\hline 181 & Spoon Ss & Junction City Con. & 207 & 88.4 \\
\hline 189 & & Wamac E & 257 & 90.2 \\
\hline 208 & Abbott $\mathrm{Se}$ & Gillespia-Wyan & 198 & 27.4 \\
\hline 200 & & Eagarvillle E & 189 & 329 \\
\hline 210 & & Raymond & 180 & 34.0 \\
\hline 173 & Caseyville Ss & Parkersburg $\mathrm{S}$ & 427 & 39.6 \\
\hline 212 & & Grandview & 171 & 47.1 \\
\hline 214 & & Ashmore $\mathrm{S}$ & 128 & 43.3 \\
\hline \multicolumn{5}{|c|}{ MISSISSIPPIAN } \\
\hline 16 & Hardinsburg Sa & Benton N & 700 & 137.1 \\
\hline 8 & Cypress Ss & Posey & 344 & 68.4 \\
\hline 12 & & Roland C & 815 & 107.7 \\
\hline 139 & & Bártelso W & 293 & 44.5 \\
\hline 140 & & Irvington $W$ & 445 & 106.4 \\
\hline 146 & & Francis Mills & 815 & 103.5 \\
\hline 186 & & Posey & 337 & 63.6 \\
\hline 196 & & Iola C & 694 & 129.0 \\
\hline 199 & & Hord N & 741 & 134.8 \\
\hline 2006 & & New Bellair & 355 & 527 \\
\hline 4 & Bethel Ss & Shattuc N & 440 & 90.5 \\
\hline 6 & Yankeetown Ss & Omega & 695 & 138.1 \\
\hline 141 & & Posea S & 383 & 76.5 \\
\hline 148 & & Pana C & 466 & 105.7 \\
\hline 149 & & Stewardson W & 585 & 127.4 \\
\hline 150 & & La Clede & 712 & 124.8 \\
\hline 163 & & Roaches & 610 & 121.5 \\
\hline 164 & & Waltonville & 750 & 136.5 \\
\hline 182 & & Irvington $\mathrm{N}$ & 448 & 96.0 \\
\hline 211 & & Lakewood & 515 & 100.2 \\
\hline 14 & Aux Vases Ss & Bungay Con. & 985 & 1560 \\
\hline 19 & & Clay City Con. & 947 & 149.7 \\
\hline 143 & & Buckner & 793 & 137.5 \\
\hline 154 & & Stiritz & 770 & 134.1 \\
\hline 156 & & Galatia N & 900 & 127.9 \\
\hline 157 & & Eldorado W & 902 & 110.5 \\
\hline 161 & & Broughton N & 960 & 121.3 \\
\hline 167 & & Burnt Prairie SW & 1017 & 117.7 \\
\hline 168 & & Sumpter $W$ & 965 & 119.5 \\
\hline 10 & & Locust Grove S & 968 & 137.9 \\
\hline 178 & & Omega & 720 & 126.1 \\
\hline 198 & & Hord N & 803 & 131.4 \\
\hline 205 & & Toliver E & 835 & 132.3 \\
\hline 245 & & Thompsonville $\mathrm{N}$ & 896 & 133.9 \\
\hline 246 & & Thompsonville $\mathrm{N}$ & & 134.8 \\
\hline 247 & & Thompsonville $\mathrm{N}$ & & 133.0 \\
\hline 248 & & Thompsonville N & & 132.6 \\
\hline 249 & & Thompsonville N & & 135.0 \\
\hline 250 & & Thompsonville $\mathrm{N}$ & & 133.5 \\
\hline 1 & Ste. Genevieve Ls & Markham City & 929 & 152.7 \\
\hline 15 & & Parkersburg Con. & 984 & 130.9 \\
\hline 17 & & Zenilh E & 963 & 154.0 \\
\hline 22 & & Rinard N & 964 & 156.2 \\
\hline 126 & & Bluford & 923 & 114.2 \\
\hline 127 & & Lynchburg & 928 & 140.2 \\
\hline 108 & & Divide $\mathbf{S}$ & 873 & 125.8 \\
\hline 129 & & Flora SE & 937 & 147.4 \\
\hline 130 & & Deering City E & $\mathbf{9 0 4}$ & 132.5 \\
\hline 133 & & Sumner & 689 & 70.2 \\
\hline 134 & & Bogata S & $\mathbf{9 3 7}$ & 139.5 \\
\hline 135 & & Bogata S & & 86.8 \\
\hline 136 & & Newton $\mathbf{N}$ & 870 & 130.3 \\
\hline 137 & & Hidalgo & 785 & 840 \\
\hline 138 & & Sigel & 716 & 117.8 \\
\hline 151 & & Hunt City & 70 & 109.1 \\
\hline 180 & & Spring Garden & 942 & 128.7 \\
\hline 165 & & King N & 887 & 134.0 \\
\hline $16 \theta$ & & Maple Grove SC & $\mathbf{9 9 8}$ & 1223 \\
\hline 171 & & Schnell E & 949 & 137.9 \\
\hline 179 & & Omega & 759 & 125.8 \\
\hline 194 & & Louisville & 873 & 129.4 \\
\hline 196 & & Iola S & 799 & 125.4 \\
\hline 197 & & Toliver $\mathrm{E}$ & 802 & 123.5 \\
\hline 202 & & Stringtown $\mathbf{E}$ & 922 & 122.2 \\
\hline $20 B$ & & Amity & 89 & 122.1 \\
\hline 204 & & Teutopolis & 732 & 116.7 \\
\hline
\end{tabular}

include some of the major petroleum pay zones in the basin. Although a specific reservoir in each field is normally represented by a single water sample, six samples were obtained from a single reservoir in one field (Thompsonville $N$ ) in order to examine internal chemical and isotopic variability. Sample salinities (Table 1) range from 27.4 to $156.0 \mathrm{~g} / \mathrm{L}$, generally increasing with production depth in individual stratigraphic units.

\section{SAMPLE COLLECTION AND ANALYSIS}

Formation-water samples analyzed in this study are from a larger suite collected during the perind 1984-1989; general sampling procedures have been described in STUEBER et al. (1987). For the seventyfour water samples reported here, fifty-nine were collected from the bleeder valve on the wellhead and the others from the separator tank. All samples were passed through a $0.45 \mu \mathrm{m}$ filter, acidified to $\mathrm{pH}$ $<2$ with Ultrex concentrated $\mathrm{HNO}_{3}$, and stored in polyethylene bottles. Cation concentrations (Table 2) were determined by inductively coupled plasma-atomic emission spectrometry on a Leeman Labs Plasma-Spec III instrument, with a precision ranging from $\pm 1 \%$ for $\mathrm{Sr}$ to $\pm 7 \%$ for $\mathrm{K}$. Concentrations of anions were determined by ion chromatography using a Dionex $4000 \mathrm{i}$ series instrument with AS2 and AS5 columns and suppressed conductivity detection; analytical precision is $\pm 1 \%$ for $\mathrm{Cl}$ and $\mathrm{SO}_{4}$, and $\pm 3 \%$ for $\mathrm{Br}$. Analyses of several unacidified subsamples showed that $\mathrm{HNO}_{3}$ treatment had no detectable effect on the reported anion analyses.

Strontium for isotopic analysis was extracted from water samples using standard ion chromatographic techniques. Strontium isotopic compositions were analyzed at Washington University (WU) on a VG 354 thermal emission mass spectrometer, equipped with three independent Faraday cups for simultaneous ion collection (POPP et al., 1986), and at Argonne National Laboratory (ANL) on a VG 54R mass spectrometer. Based on reproducibility of NBS-987 analyses, the analytical error in ${ }^{87} \mathrm{Sr} /{ }^{86} \mathrm{Sr}$ ratios measured at $\mathrm{WU}$ is $\pm 0.00002(2 \sigma)$ whereas at ANI it is \pm 0.00006 . Analyses of NBS987 yielded mean values of 0.71024 at WU and 0.71022 at ANL; Sr isotope ratios recorded in Table 2 , which include thirteen analyses reported previously (STUEBER et al., 1987), have been adjusted to the conventional value of 0.71014 for ${ }^{87} \mathrm{Sr} /{ }^{86} \mathrm{Sr}$ in NBS-987.

A subset of twenty-six of the Mississippian-Pennsylvanian water samples was selected for boron isotopic analysis. For comparison, we also analyzed seven formation-water samples from Silurian-Devonian strata; chemical analyses of these samples are reported in STUEBER and WALTER (1991). Boron isulopic analyses were conducted at the University of Texas by tri-methyl borane distillation and analysis as the cesium borate ion (SPIVACK et al., 1987). Data are reported in standard $\delta$ notation, relative to NBS borate SRM 951.

Ten whole-rock core samples of New Albany shales were also analyzed for concentrations of major, minor, and trace elements and Sr isotopic compositions. The core samples, from six counties within Illinois, were obtained from the geological samples library at the Illinois State Geological Survey. After the rock powders were digested in $\mathrm{HF}$ and treated with $\mathrm{HNO}_{3}+\mathrm{HClO}_{4}$, the sample solutions were analyzed according to procedures already described.

\section{CHLORIDE-BROMIDE RELATIONS}

It is currently held that the origin of high formation-water salinity is explained by subsurface dissolution of evaporites and/or by infiltration of subaerially evaporated seawater (e.g., HANOR, 1987). The Illinois basin stratigraphic section today is characterized by a paucity of evaporites and the absence of bedded halite. Through a comparison of formation-water compositions with the $\mathrm{Cl}-\mathrm{Br}$ seawater evaporation trend (CARPENTER, 1978), STUEBER and WALTER (1991) showed that formation-water salinity in Silurian-Devonian strata of the Illinois basin is most simply interpreted as the result of subaerial evaporation of seawater. Chloride-bromide relations in sixty-eight formation-water samples from Mississippian and Pennsylvanian strata in the basin are illustrated in Fig. 3a. These brine compositions in general are significantly enriched in $\mathrm{Cl}$ relative to the evaporation trajectory and are more variable in $\mathrm{Cl} / \mathrm{Br}$ than waters from Silurian-Devonian strata (Fig. 3b). This relation holds for brines from individual reservoirs as well as for the complete suite of samples. Some Mississippian-Pennsylvanian samples, from shallow silici- 


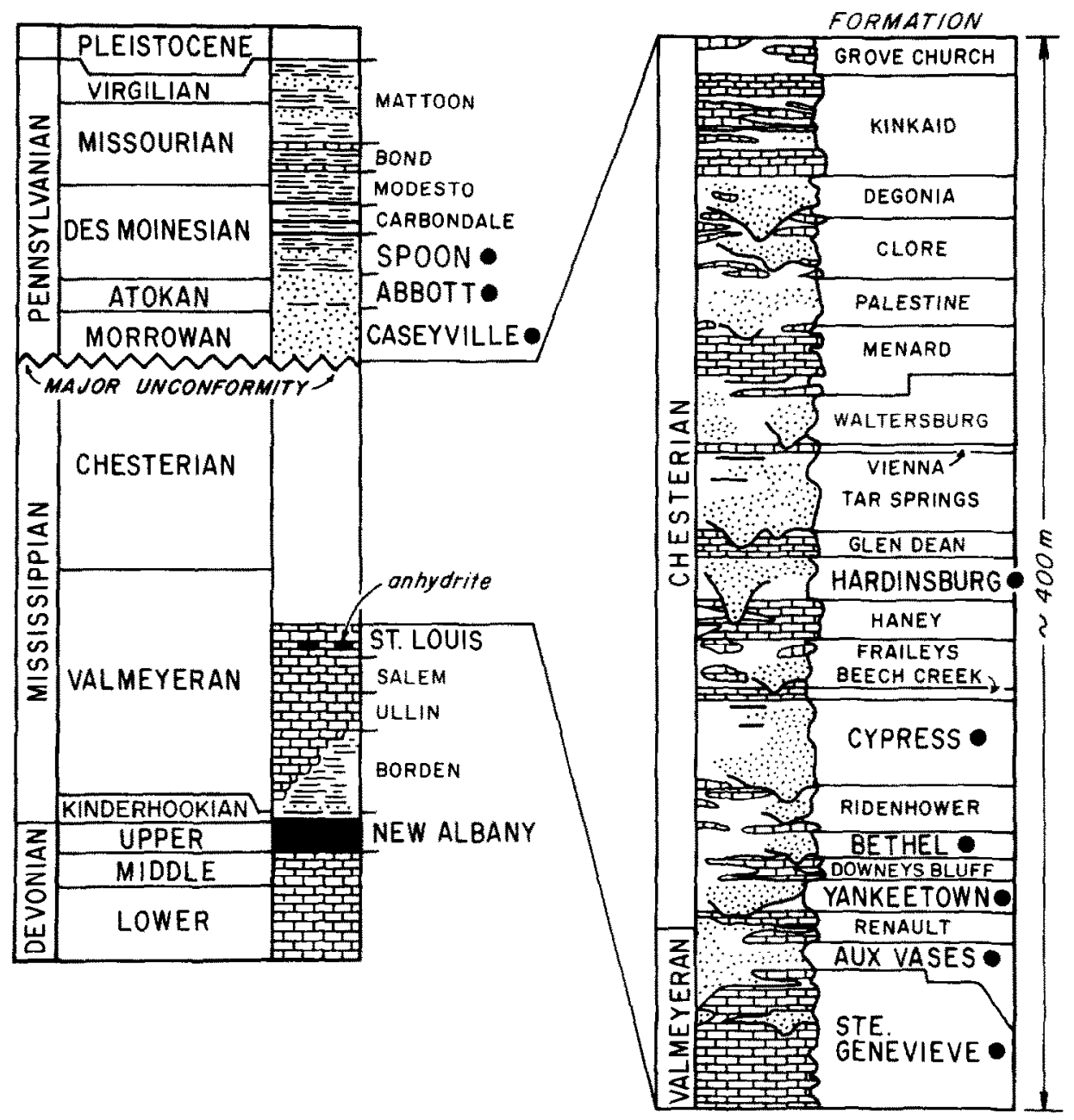

- Sampled Reservior

Blank Areas are Shales

FiG. 2. Generalized geological column of Mississippian and Pennsylvanian strata in southern Illinois, showing units from which formation-water samples were obtained. Modified from SWANN (1963).

clastic reservoirs, have $\mathrm{Br}$ levels less than seawater (Fig. 3a); these brines have apparently experienced extensive dilution by infiltrating meteoric water.

Elevated $\mathrm{Cl} / \mathrm{Br}$ ratios in Mississippian-Pennsylvanian brines relative to seawater are most readily explained by congruent dissolution of first-cycle halite, which commonly contains only about 70 ppm $\mathrm{Br}$ (HOLSER, 1979). Such halite dissolution should also have increased $\mathrm{Na} / \mathrm{Br}$ in the formation waters; WALTER et al. (1990) used $\mathrm{Cl} / \mathrm{Br}-\mathrm{Na} / \mathrm{Br}$ relations for these samples to calculate percentages of $\mathrm{NaCl}$ contributed to each by congruent halite dissolution, which yielded an average of about $30 \%$. They pointed out that if the additional $\mathrm{NaCl}$ in these brines is attributable to seawater evaporation, it is unlikely that the brines were concentrated significantly beyond the point of halite saturation because none of the samples have $\mathrm{Cl} / \mathrm{Br}$ ratios less than that of seawater (Fig. 3a). These authors noted, however, that some excursions past saturation were required in order to produce the halite for later dissolution, though only small amounts are needed to meet the mass-balance requirements in the formation-water samples (average of only about $25 \mathrm{~g} \mathrm{NaCl} / \mathrm{L}$ ).
The St. Louis Limestone (Fig. 2) is predominantly a cherty lime mudstone interbedded with other carbonate facies (TREWORGY, 1991). KRUMBEIN (1951) and MCGREGOR (1954) were first to note the occurrence of significant gypsum and anhydrite beds in this formation; these represent the only reported evaporite deposits in the stratigraphic section of the Illinois basin above the Ordovician. According to CLUFF and LINEBACK ( 1981), the St. Louis carbonates were deposited in shallow subtidal, highly restricted environments. Intertidal and supratidal conditions predominated at the margins of the basin, where evaporites were formed. Thus, MCGREGOR (1954) reported gypsum and/or anhydrite beds with a total thickness of about $20 \mathrm{~m}$ in the lower half of the St. Louis Limestone in southwestern Indiana. MCGRAIN and HELTON (1964) found that these evaporites extended into northwestern Kentucky, and SAXBY and LAMAR (1957) described gypsum/anhydrite beds in the lower St. Louis within a broad belt across central Illinois. WALTER et al. (1990) suggested that the absolute masses of $\mathrm{NaCl}$ required to account for elevated $\mathrm{Cl} / \mathrm{Br}$ in Mississippian-Pennsylvanian brines could probably be found in small amounts of halite occluded in 
Table 2. Chemical and $\mathrm{Sr}$ isotopic analyses of formation-water samples (concentrations in $\mathrm{mg} / \mathrm{L}$ )

\begin{tabular}{|c|c|c|c|c|c|c|c|c|c|c|c|c|c|c|c|}
\hline Sample & $\mathrm{Na}$ & $\mathrm{ca}$ & $M$ & $\mathbf{K}$ & Sx & d & $\mathbf{n r}$ & Sot & $\mathbf{8 i}$ & E & $L$ & $\mathrm{Ba}$ & Ec & $\mathrm{Mn}$ & ${ }^{87} \mathrm{Sr} / 86_{\mathrm{S}}$ \\
\hline & \multicolumn{15}{|c|}{ PENNSYLVANIAN } \\
\hline 181 & 30900 & 2070 & 790 & 93 & 103 & 54300 & 90.5 & nd & 3.70 & 0.74 & 1.74 & 34.1 & 9.66 & 0.73 & 0.71052 \\
\hline 189 & 31300 & 1990 & 927 & 116 & 107 & 55560 & 96.6 & nd & 4.67 & 0.81 & 2.44 & 61.3 & 13.1 & 0.45 & 0.71051 \\
\hline 208 & 9860 & 397 & 312 & 53 & 77 & 16630 & 53.0 & nd & 4.30 & 2.11 & 0.88 & 14.6 & 0.26 & 0.29 & 0.70981 \\
\hline 200 & 11700 & 476 & 342 & 51 & 74 & 20110 & 67.8 & nd & 3.03 & 1.61 & 0.57 & 13.6 & 18.2 & 1.08 & 0.70986 \\
\hline 210 & 12000 & 496 & 351 & 37 & 47 & 20090 & 65.7 & nd & 3.68 & 1.29 & 0.58 & 38.6 & 48.7 & 1.32 & 0.70977 \\
\hline 173 & 14500 & 551 & 266 & 54 & 28 & 24170 & 46.1 & nd & 4.67 & 1.88 & 0.80 & 16.0 & 0.23 & 0.43 & 0.71028 \\
\hline 212 & 17300 & 506 & 352 & 87 & 35 & 28730 & 52.3 & nd & 3.36 & 1.44 & 1.28 & 39.0 & 0.06 & 0.58 & 0.70960 \\
\hline \multirow[t]{2}{*}{214} & 15800 & 491 & 366 & 93 & 38 & 26350 & 46.1 & nd & 5.42 & 2.15 & 2.53 & 44.3 & 26.3 & 0.80 & 0.70965 \\
\hline & \multicolumn{15}{|c|}{ MISSISSIPPIAN } \\
\hline 16 & 44100 & 5200 & 1890 & 85 & 453 & 84750 & 144 & nd & 4.44 & 2.14 & 3.56 & 474 & 0.25 & 1.38 & 0.70995 \\
\hline 8 & 21800 & 2780 & 900 & 130 & 145 & 42290 & 120 & 108 & 4.77 & 2.82 & 4.74 & 4.01 & 138 & 7.04 & 0.70928 \\
\hline 12 & 36500 & 4910 & 1090 & 172 & 402 & 64430 & 160 & 17 & 6.65 & 3.17 & 8.63 & 22.2 & 0.22 & 0.92 & 0.71041 \\
\hline 139 & 13600 & 6410 & 585 & 47 & 79 & 29670 & 77.0 & nd & 5.19 & 2.22 & 2.61 & 2.58 & 1.70 & 0.17 & 0.70911 \\
\hline 140 & 34100 & 3580 & 1650 & 166 & 273 & 65370 & 136 & nd & 4.17 & 2.28 & 4.97 & 103 & 53.9 & 2.04 & 0.70966 \\
\hline 146 & 33300 & 4810 & 969 & 152 & 352 & 65650 & 138 & nd & 4.78 & 2.48 & 7.02 & 14.1 & 95.7 & 2.62 & 0.71041 \\
\hline 285 & 21200 & 1730 & 852 & 80 & 135 & 39800 & 114 & nd & 4.09 & 2.36 & 3.90 & 139 & 43.9 & 2.49 & 0.70938 \\
\hline 196 & 39800 & 4910 & 1410 & 192 & 236 & 79310 & 147 & 9 & 6.28 & 4.63 & 5.56 & 79.8 & 2850 & 38.7 & 0.70983 \\
\hline 199 & 45300 & 4360 & 1330 & 155 & 191 & 82800 & 164 & 529 & 5.94 & 2.50 & 4.88 & 2.13 & 2.72 & 2.17 & 0.70995 \\
\hline 206 & 18100 & 3570 & 425 & 61 & 71 & 30330 & 54.6 & nd & 4.73 & 1.78 & 1.49 & 24,3 & 18.7 & 0.52 & 0.70965 \\
\hline 4 & 30200 & 2300 & 1260 & 106 & 135 & 56350 & 165 & nd & 5.85 & 3.40 & 7.21 & 2.30 & 13.7 & 0.72 & 0.70921 \\
\hline 6 & 44500 & 5370 & 1830 & 211 & 375 & 85490 & 186 & 41 & 6.02 & 4.12 & 8,24 & 7.59 & 38.2 & 1.82 & 0.70943 \\
\hline 141 & 25700 & 2050 & 1010 & 116 & 176 & 46300 & 128 & 2 & 3.35 & 2,00 & 5.93 & 3.28 & 0.14 & 0.69 & 0.70926 \\
\hline 148 & 35700 & 3400 & 1240 & 260 & 214 & 64650 & 143 & nd & 5.70 & 3.64 & 4.59 & 50.0 & 33.1 & 2.21 & 0.70945 \\
\hline 149 & 43100 & 3990 & 1590 & 146 & 170 & 78240 & 171 & 52 & 0.58 & 3.24 & 10.8 & 1.02 & 7.80 & 1.60 & 0.70939 \\
\hline 150 & 41900 & 4150 & 1610 & 206 & 236 & 76440 & 186 & nd & 5.15 & 3.68 & 9.37 & 58.2 & 5.27 & 1.16 & 0.70929 \\
\hline 163 & 39500 & 4810 & 1610 & 180 & 327 & 74780 & 175 & nd & 4.79 & 3.12 & 7.75 & 125 & 17.2 & 1.38 & 0.70950 \\
\hline 164 & 44900 & 5210 & 1540 & 196 & 282 & 83740 & 180 & 457 & 5.08 & 2.27 & 6.56 & 0.77 & 9.12 & 1.27 & 0.70976 \\
\hline 182 & 31700 & 2900 & 1310 & 145 & 197 & 59510 & 160 & nd & 4.29 & 9.08 & 6.73 & 12.0 & 12.0 & 0.90 & 0.70939 \\
\hline 211 & 34400 & 2520 & 1250 & 106 & 142 & 61580 & 145 & 12 & 5.58 & 3.27 & 6.00 & 5.43 & 0.17 & 0.36 & 0.70945 \\
\hline 14 & 49500 & 6950 & 1870 & 307 & 265 & 95670 & 244 & 1200 & 6.65 & 5.33 & 10.0 & 0.58 & 17.8 & 0.56 & 0.70953 \\
\hline 19 & 48700 & 6410 & 1580 & 254 & 189 & 90610 & 187 & 1680 & 14.1 & 4,23 & 7.95 & 0.44 & 28.0 & 0.65 & 0.70967 \\
\hline 143 & 43900 & 6090 & 1810 & 171 & 401 & 84550 & 127 & 339 & 4.76 & 2.83 & 8.08 & 1,79 & 5.71 & 0.81 & 0.70954 \\
\hline 164 & 44300 & 4660 & 1680 & 218 & 236 & 82170 & 193 & 612 & 5.28 & 2.41 & 10.9 & 1.92 & 0.54 & 1.10 & 0.70928 \\
\hline 156 & 39800 & 5710 & 2080 & 303 & 381 & 78750 & 218 & 601 & 5.73 & 4.89 & 12.2 & 7,10 & 0.66 & 0.16 & 0.70908 \\
\hline 157 & 34500 & 5300 & 1670 & 281 & 217 & 67180 & 215 & 1110 & 5.43 & 3.52 & 14.6 & 0.42 & 1.21 & 0.40 & 0.70971 \\
\hline 161 & 38700 & 5170 & 1580 & 267 & 269 & 74680 & 206 & 423 & 6.65 & 6.04 & 10.7 & 0.95 & 0.79 & 0.49 & 0.70929 \\
\hline 167 & 36500 & 5390 & 1890 & 253 & 137 & 71280 & 227 & 1960 & 8.21 & 8.26 & 11.0 & 0.21 & 0.18 & 0.26 & 0.70900 \\
\hline 168 & 36800 & 6270 & 1550 & 193 & 209 & 73050 & 211 & 1230 & 5.99 & 4.75 & 6.65 & 0.40 & 5.46 & 0.64 & 0.70988 \\
\hline 170 & 44500 & 5590 & 1590 & 234 & 153 & 84040 & 203 & 1590 & 6.33 & 4.81 & 8.10 & 0.38 & 0.18 & 0.52 & $0.709^{14}$ \\
\hline 178 & 40200 & 5070 & 1680 & 237 & 361 & 78330 & 182 & 3 & 4.56 & 4.22 & 9.02 & 38.3 & 3.28 & 0.74 & 0.70939 \\
\hline 198 & 42700 & 5210 & 1700 & 252 & 355 & 80800 & 178 & 139 & 6.05 & 3.69 & 8.08 & 9.66 & 9.53 & 0.88 & 0.70926 \\
\hline 205 & 44900 & 4250 & 1270 & 232 & 212 & 80690 & 165 & 520 & 8.03 & 3.98 & 7.41 & 1.14 & 0.23 & 0.47 & 0.70936 \\
\hline 245 & 42500 & 6290 & 1790 & 205 & 365 & 81800 & 209 & 702 & 6.35 & 8.74 & 9.46 & 0.68 & 7.18 & 0.46 & 0.70954 \\
\hline 1 & 49800 & 4780 & 2840 & 315 & 650 & 93780 & 247 & 254 & 7.79 & 8.16 & 14.4 & 2.44 & 1.49 & 0.32 & 0.70812 \\
\hline 15 & 40300 & 6320 & 2360 & 241 & 135 & 79220 & 237 & 2040 & 9.09 & 10.1 & 13.4 & 0.38 & 1.34 & 0.26 & 0.70819 \\
\hline 17 & 50000 & 5570 & 2590 & 369 & 343 & 94250 & 211 & 680 & 7.68 & 6.45 & 11.0 & 1.16 & 0.57 & 0.13 & 0.70837 \\
\hline 22 & 52600 & 4460 & 2550 & $\mathrm{NA}$ & 580 & 95730 & 278 & NA & NA & NA & NA & NA & NA & $\mathrm{NA}$ & 0.70789 \\
\hline 126 & 39600 & 3000 & 1200 & 184 & 199 & 69360 & 143 & 521 & 8.29 & 3.68 & 4.91 & 0.74 & 0.25 & 0.18 & 0.70890 \\
\hline 127 & 45900 & 5060 & 2260 & 274 & 531 & 85580 & 208 & 379 & 5.95 & 5.90 & 9.75 & 1.71 & 0.84 & 0.52 & 0.70860 \\
\hline 128 & 41200 & 4540 & 1630 & 520 & 150 & 75530 & 195 & 2110 & 9.40 & 10.4 & 19.2 & 1.44 & 0.22 & 0.17 & 0.70854 \\
\hline 129 & 47900 & 6020 & 2120 & 349 & 153 & 89120 & 196 & 1510 & 5.33 & 5.82 & 9.12 & 0.41 & 1.03 & 0.39 & 0.70837 \\
\hline 130 & 41600 & 5550 & 2270 & 300 & 450 & 81690 & 219 & 441 & 7.89 & 5.83 & 9.55 & 1.05 & 0.26 & 0.26 & 0.70891 \\
\hline 133 & 24100 & 2390 & 1040 & 119 & 80 & 41890 & 125 & 425 & 5.40 & 4.15 & 6.48 & 0.51 & 0.34 & 1.32 & 0.70850 \\
\hline 134 & 46800 & 5360 & 1700 & 320 & 121 & 88090 & 170 & 1880 & 7.80 & 8.25 & 9.40 & 0.27 & 0.25 & 0.11 & 0.70820 \\
\hline 135 & 30100 & 2780 & 730 & 151 & 66 & 49900 & 100 & 3020 & 11.1 & 3.31 & 3.65 & 0.18 & 0.19 & 0.08 & 0.70893 \\
\hline 136 & 42500 & 5390 & 1640 & 248 & 113 & 78320 & 155 & 1900 & 7.84 & 7.07 & 10.1 & 0.43 & 0.26 & 0.18 & 0.70806 \\
\hline 137 & 28400 & 2260 & 1150 & 170 & 153 & 49310 & NA & 2550 & 9.10 & 7.63 & 14.6 & 0.51 & 0.20 & 0.13 & 0.70800 \\
\hline 138 & 39000 & 3140 & 1930 & 192 & 684 & 72410 & 167 & 260 & 6.78 & 5.26 & 11.7 & 2,41 & 3.36 & 0.60 & 0.70835 \\
\hline 151 & 36100 & 3820 & 1330 & 188 & 79 & 64730 & 122 & 2670 & 7.18 & 0.10 & 8.38 & 0.69 & 0.20 & 0.11 & 0.70790 \\
\hline 160 & 42900 & 3960 & 2180 & 413 & 228 & 77580 & 204 & 1190 & 7.94 & 8.96 & 17.1 & 0.62 & 0.27 & 0.65 & 0.70853 \\
\hline 165 & 44300 & 3970 & 2750 & 289 & 623 & 81650 & 204 & 180 & 7.57 & 6.54 & 10.3 & 1.98 & 0.31 & 0.42 & 0.70827 \\
\hline 160 & 38400 & 5920 & 2260 & 251 & 128 & 73190 & 220 & 1910 & 7.44 & 9.57 & 10.5 & 0.93 & 0.24 & 0.11 & 0.70820 \\
\hline 171 & 44400 & 5080 & 2630 & 304 & 304 & 83630 & 188 & 1340 & 9.15 & 7.18 & 13,0 & 0.88 & 0.26 & 1.17 & 0.70803 \\
\hline 179 & 40200 & 3890 & 2620 & 283 & 471 & 77660 & 200 & 470 & 7.12 & 9.92 & 15.6 & 0.57 & 0.25 & 0.75 & 0.70805 \\
\hline 594 & 43600 & 4460 & $13 m$ & 248 & 202 & 78470 & 167 & 947 & 8.91 & 4.66 & 6.31 & 0,75 & 0.30 & 0.22 & 0.70000 \\
\hline 195 & 41900 & 4670 & 1710 & 259 & 237 & 76080 & 179 & 344 & 6.38 & 4.82 & 9.82 & 1.94 & 0.39 & 0.75 & 0.70899 \\
\hline 197 & 41500 & 3670 & 1700 & 232 & 261 & 74940 & 156 & 982 & 8.73 & 5.18 & 7.32 & 0.55 & 0.26 & 0.18 & 0.70846 \\
\hline 202 & 40000 & 3960 & 3080 & 244 & 279 & 73660 & 168 & 753 & 7.10 & 6.91 & 13.0 & 0.70 & 0.25 & 0.77 & 0.70782 \\
\hline 203 & 38700 & 5490 & 1940 & 240 & 120 & 73610 & 185 & 1810 & 7.18 & 6.54 & 10.0 & 0.35 & 0.27 & 0.19 & 0.70829 \\
\hline 204 & 39500 & 3080 & 1740 & 196 & 338 & 71140 & 160 & 429 & 7.12 & 5.39 & 10.7 & 0.78 & 0.24 & 0.11 & 0.70809 \\
\hline
\end{tabular}



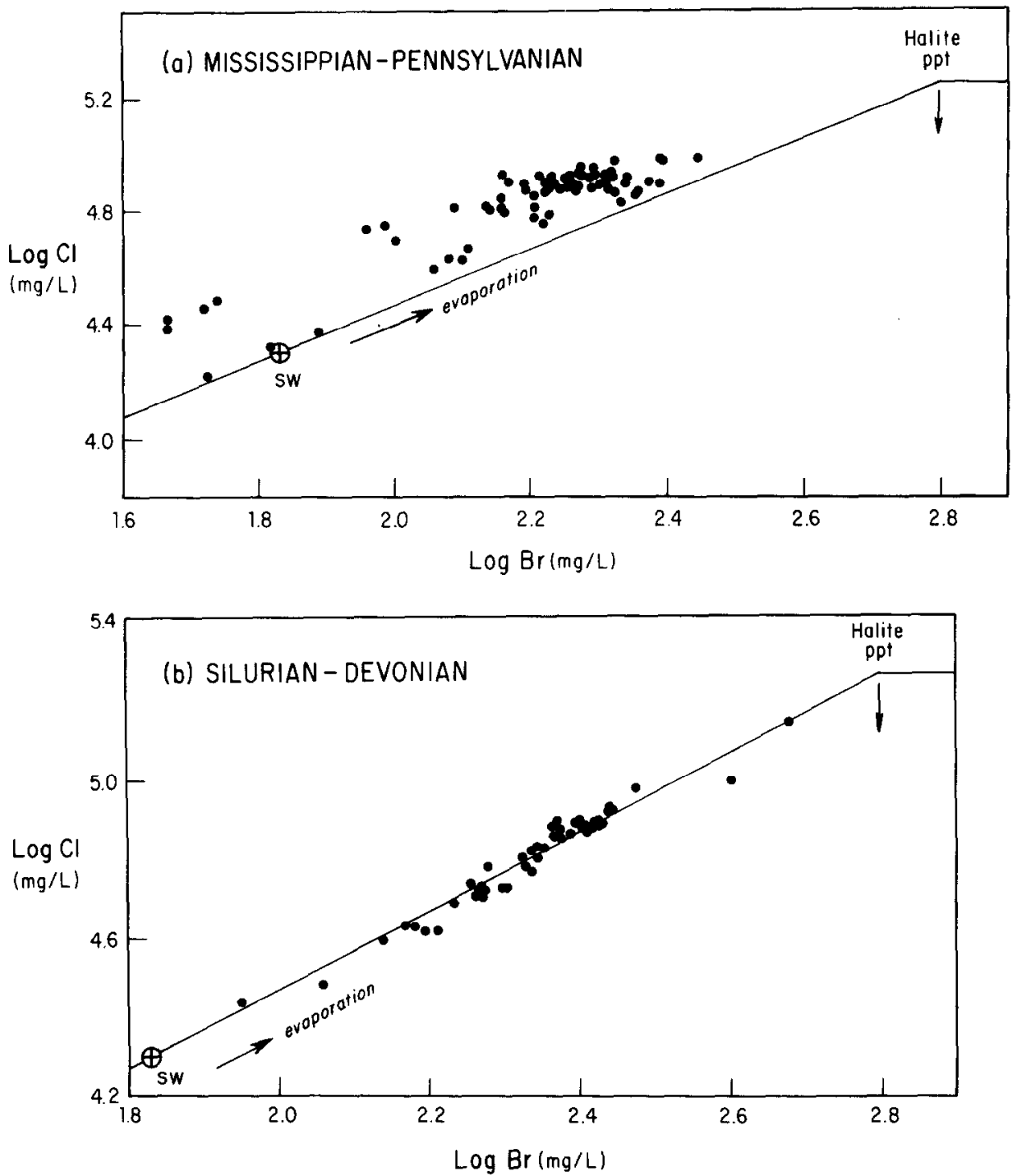

FIG. 3. (a) $\mathrm{Cl}-\mathrm{Br}$ relations in sixty-eight formation-water samples from Mississippian and Pennsylvanian reservoirs in the Illinois basin (see Figs. 1 and 2). Seawater evaporation-dilution trajectory from CARPENTER ( 1978); $S W$ indicates seawater composition. (b) Cl-Br relations in 46 formation-water samples from Silurian and Devonian reservoirs in the Illinois basin, from STUEBER and WALTER (1991).

the St. Louis evaporites. The presence of minor halite in these beds is supported by chemical analyses of core samples from the evaporite zone. SAXBY and LAMAR (1957) reported 0.15$0.69 \mathrm{wt} \% \mathrm{NaCl}$ in five samples of gypsum and anhydrite from two wells in central Illinois. MCGRAIN and HELTON (1964) presented chemical analyses of sixty-nine samples representing $23 \mathrm{~m}$ of core material from the St. Louis evaporite zone in a well in northwestern Kentucky; $\mathrm{NaCl}$ ranged from 0.24 $1.90 \mathrm{wt} \%$ in the samples.

Widespread distribution of Mississippian-Pennsylvanian brine compositions subparallel to the $\mathrm{Cl}-\mathrm{Br}$ seawater evaporation trajectory and extending to $\mathrm{Br}$ levels below seawater (Fig. 3a) suggests mixing of these formation waters with meteoric water. In testing for mixing between two waters, dissolved chloride is sometimes used as a conservative parameter in halite-free settings; under the present circumstances bromide has been used because it occurs only at trace levels in halite. In Fig. 4, $\mathrm{Na}$ vs. $\mathrm{Br}$ plots are shown for brines from
Ste. Genevieve and Aux Vases reservoirs (Fig. 4a), the Valmeyeran portion of the stratigraphic interval under study (Fig. 2), and for waters from Chesterian and Pennsylvanian reservoirs (Fig. 4b). In the latter case brine compositions form a linear trend directed toward the origin whereas the trend for Valmeyeran waters has a very large positive $\mathrm{Na}$ intercept. Scatter of data points about both trend lines reflects variable non-conservative $\mathrm{Na}$ behavior through halite dissolution and $\mathrm{Na}$ fixation on clays. A similar set of relations is revealed by $\mathrm{Cl}$ vs. Br plots for the two groups of formation waters (Fig. 5). All other cations in both groups of samples show trends directed toward the origin, as illustrated by $\mathrm{Mg}$ vs. $\mathrm{Br}$ in Fig. 6.

The large $\mathrm{Na}$ and $\mathrm{Cl}$ intercepts shown by the Valmeyeran sample trends, which yield a molar $\mathrm{Na} / \mathrm{Cl}$ ratio of about 1 , indicate that the meteoric-water component involved in mixing had dissolved halite. Evidently, as a result of a later event, formation waters in the Chesterian and Pennsylvanian 

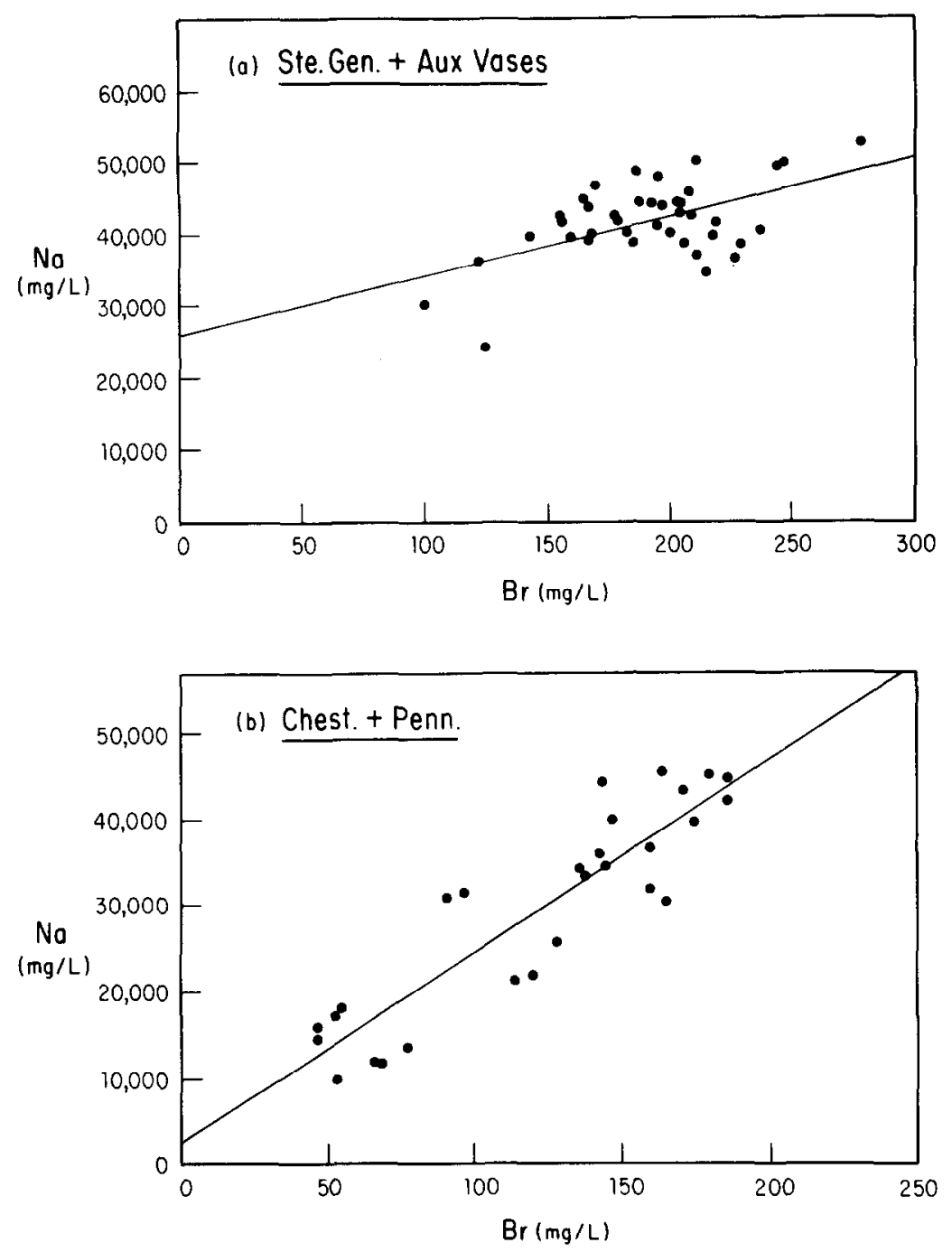

FIG. 4. Na vs. $\mathrm{Br}$ in formation waters from (a) Ste. Genevieve and Aux Vases reservoirs and (b) Chesterian and Pennsylvanian reservoirs. Regression lines have been drawn through the data points.

reservoirs were mixed with meteoric water that had not dissolved halite. It seems likely that all Mississippian-age strata would have experienced meteoric water influx, given subaerial exposure during formation of the major pre-Pennsylvanian (sub-Absaroka) unconformity (Fig. 2). Some of this water apparently dissolved minor halite occluded in the St. Louis evaporites and then mixed with and diluted formation waters in the overlying Valmeycran strata. Elevated $\mathrm{Cl} / \mathrm{Br}$ ratios in brines from all reservoirs above the St. Louis Limestone, including the Chesterian and Pennsylvanian, require considerable upward, cross-formational fluid migration. The Chesterian-Pennsylvanian brines must have undergone extensive dilution at a later time by post-Paleozoic meteoric waters, the event recorded in the mixing diagrams of Figs. $4 \mathrm{~b}$ through $6 \mathrm{~b}$.

\section{CATION-BROMIDE RELATIONS}

Although on average about $30 \%$ of the $\mathrm{NaCl}$ in formation waters from Mississippian-Pennsylvanian strata in the Illinois basin has been attributed to halite dissolution, the additional salinity of these brines can be traced to subaerial evaporation of seawater. WALTER et al. (1990) showed that when $\mathrm{Cl} / \mathrm{Br}$ ratios are plotted against $\mathrm{Na} / \mathrm{Br}$ ratios, a linear trend is defined with a positive slope consistent with equimolar increases in $\mathrm{Cl}$ and $\mathrm{Na}$ from halite dissolution. The trend, however, originates from a small field of forty-six data points (representing Silurian-Devonian brines) that lies very near the composition of seawater within these coordinates. Salinity of formation waters from Silurian-Devonian strata in the basin has been interpreted through $\mathrm{Cl}-\mathrm{Br}$ relations as being derived entirely from seawater evaporation. The paleogeographic setting of the proto-Illinois basin throughout the Paleozoic Era was favorable for subaerial evaporation of seawater. From Early Devonian through Late Permian time the basin was located very near the equator (LEIGHTON, 1991; SCOTESE et al., 1979) as an open-marinc cratonic cmbayment. According to TREWORGY and DEVERA (1991), paleomagnetic data indicate that during Middle Devonian time the proto-Illinois basin was positioned between latitudes $10-20^{\circ} \mathrm{S}$ and by latest Mississippian time it was within latitude $5^{\circ} \mathrm{S}$. The warm equatorial climate that prevailed during this interval, in combination with restricted water circulation in lagoonal environments (CLUFF and LINEBACK, 1981), could have resulted in 

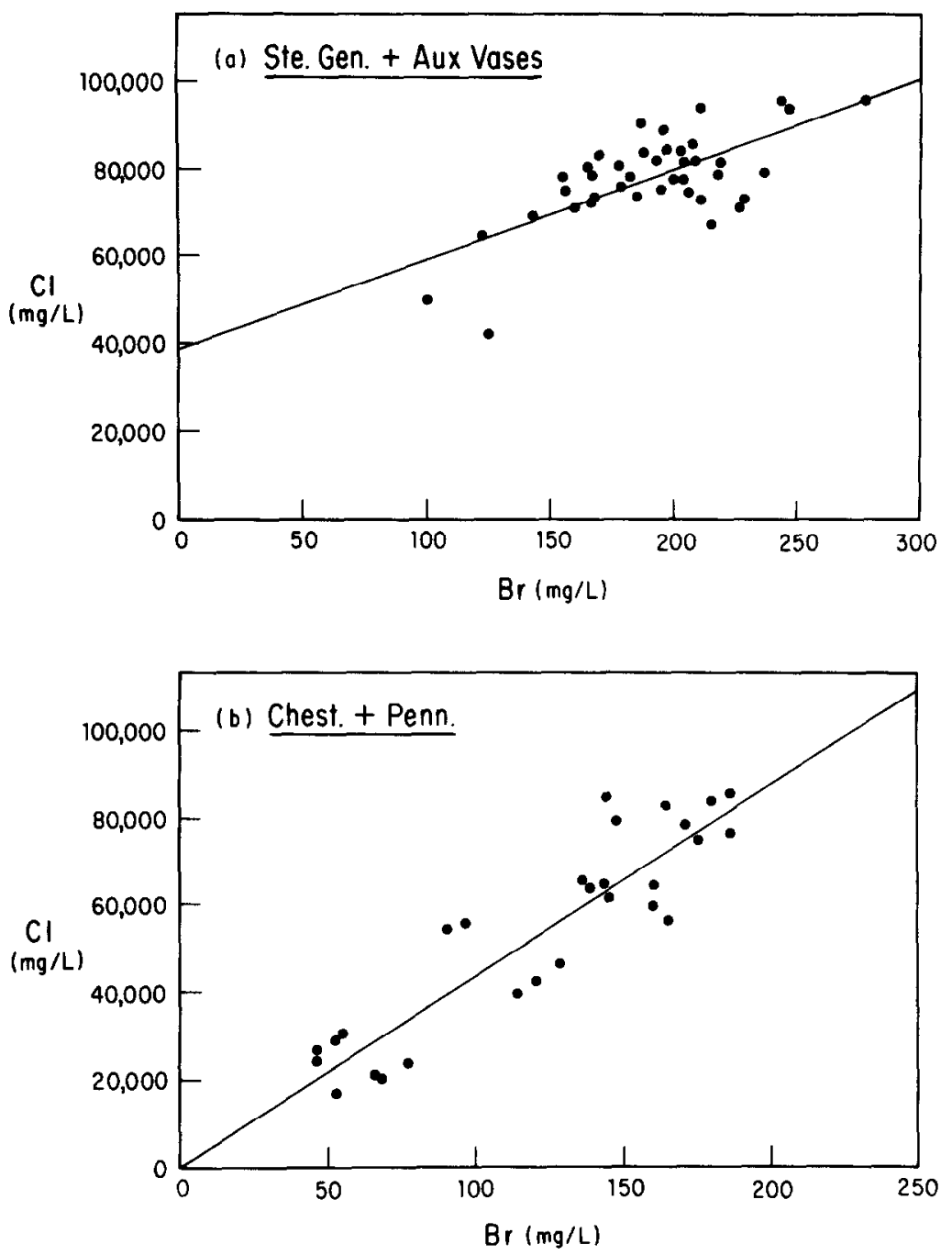

Fig. 5. Cl vs. Br in formation waters from (a) Ste. Genevieve and Aux Vases reservoirs and (b) Chesterian and Pennsylvanian reservoirs. Regression lines have been drawn through the data points.

penesaline marine conditions. In the absence of significant evaporite accumulations such surficially generated brines would have infiltrated the underlying porous sediments.

If high salinity levels of formation waters were produced initially by subaerial evaporation of seawater, subsequent changes in chemical composition resulting from water-rock interactions in the subsurface can be evaluated through a comparison of present formation-water compositions with cation- $\mathrm{Br}$ evaporation trends. Bromide anions generally do not participate in diagenetic reactions in evaporite-free strata, and congruent dissolution of halite will release negligible amounts of Br. WALTER et al. (1990) determined that the brines from Mississippian-Pennsylvanian strata under consideration here acquired about $25 \mathrm{~g} \mathrm{NaCl} / \mathrm{L}$ through halite dissolution. Assuming a $\mathrm{Br}$ level of $70 \mathrm{ppm}$ in halite (HOLSER, 1979), such dissolution would contribute less than $2 \mathrm{mg} / \mathrm{L}$ $\mathrm{Br}$ to the formation waters, an amount that is within the analytical uncertainty of our $\mathrm{Br}$ data. Halite recrystallization (incongruent halite dissolution), which preferentially releases $\mathrm{Br}$ in solutions near equilibrium with respect to halite (LAND and Prezbindowski, 1981; Stoessel and CARPENTER, 1986), should not have been a factor in this case because halite is extremely undersaturated in the present formation waters and it is unlikely that the waters responsible for halite dissolution were near halite saturation.

Sodium-bromide relations in formation waters from Mississippian-Pennsylvanian strata are shown in Fig. 7a. Sodium concentrations generally lie significantly above the seawater evaporation trajectory, analogous to $\mathrm{Cl}$ concentrations (Fig. $3 \mathrm{a})$, reflecting the acquisition of $\mathrm{Na}$ by these formation waters through halite dissolution in the subsurface. On average, $\mathrm{Na}$ concentrations have been enriched by about $43 \%$ as indicated by a mean $\mathrm{Na} / \mathrm{Br}$ ratio of 233 compared with a value of 163 for seawater (Table 3 ). Widespread distribution of data points subparallel to the evaporation trajectory and its extension to $\mathrm{Br}$ levels below seawater ( Fig. 7a) illustrate the effect of meteoric water dilution on brine salinities. STUEBER and WALTER (1991) found that Na in formation waters from SilurianDevonian strata in the Illinois basin has been depleted by about $9 \%$ (Table 3 ), probably through interaction with clay 

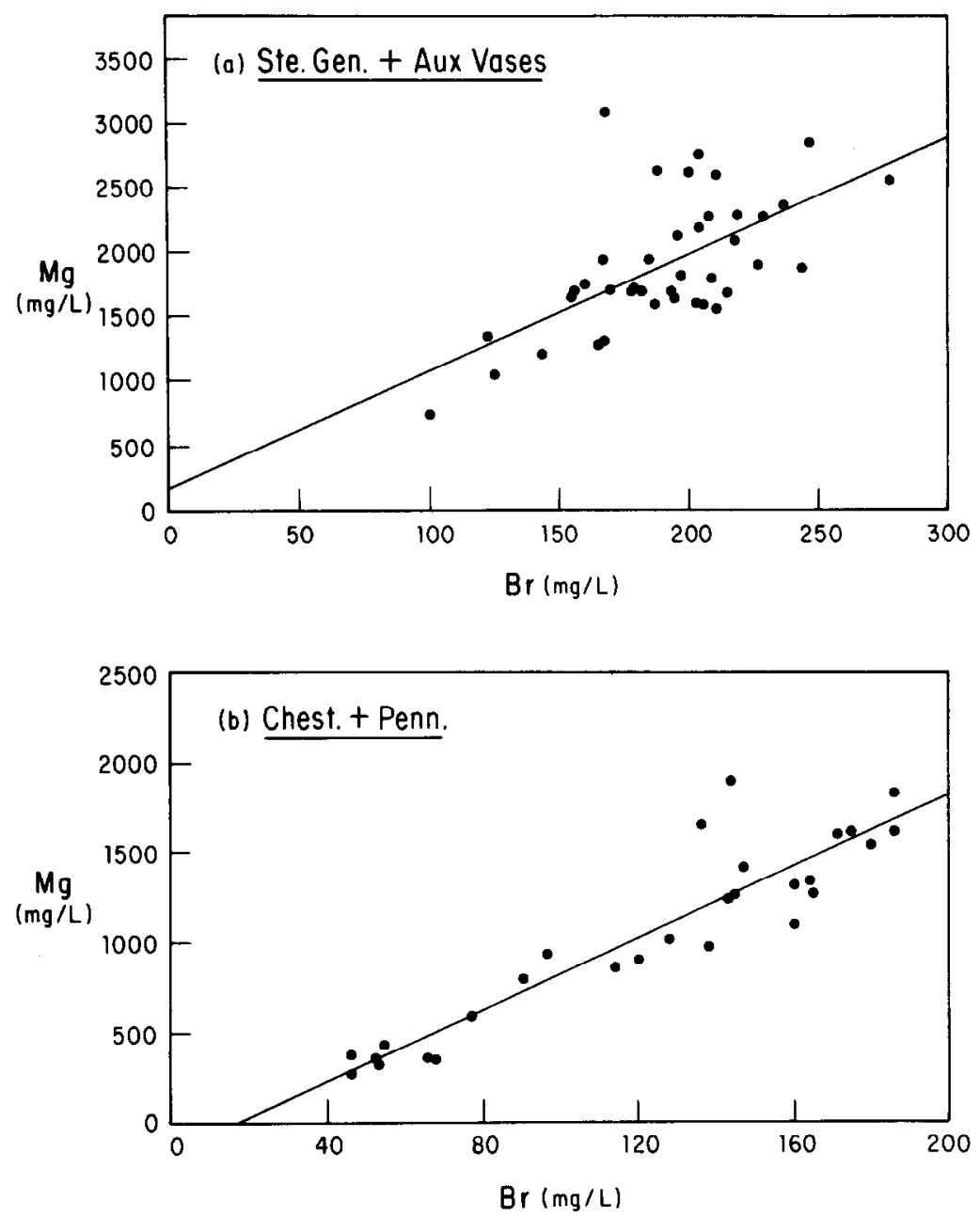

FIG. 6. $\mathrm{Mg}$ vs. $\mathrm{Br}$ in formation waters from (a) Ste. Genevieve and Aux Vases reservoirs and (b) Chesterian and Pennsylvanian reservoirs. Regression lines have been drawn through the data points.

minerals (NESBITT, 1985). Sodium fixation during clay diagenesis has undoubtedly reduced the subsurface Na enrichment of Mississippian-Pennsylvanian brines to some degree, as their average $\mathrm{Na} / \mathrm{Cl}$ enrichment relative to seawater has a molar ratio of 0.8 . Although Mississippian-Pennsylvanian sandstones are mature quartzarenites which generally contain less than one percent feldspar (POTTER, 1962; POTTER and GLASS, 1958), it is possible that larger amounts of plagioclase feldspar were originally present. Thus albitization of Ca-plagioclase also may have reduced $\mathrm{Na}$ in these formation waters.

NESBITT $(1980,1985)$ studied mineral-formation water interactions in Mississippian and Pennsylvanian siliciclastic rocks of the Illinois basin, using brine analytical compilations of MEENTS et al. (1952) and GraF et al. (1966). He concluded that the formation waters have not dissolved significant amounts of halite. The evidence presented here and in WALTER et al. (1990) clearly demonstrates that halite dissolution has played a major role in the chemical evolution of these waters.

Potassium-bromide relations (Fig. $7 \mathrm{~b}$ ) reveal marked $\mathrm{K}$ depletion in Mississippian-Pennsylvanian brines relative to evaporated seawater $(80 \%$ on average; Table 3 ). STUEBER and WALTER (1991) found an average $\mathrm{K}$ depletion of $71 \%$ in waters from Silurian-Devonian strata (Table 3), which they attributed to reaction with low-K clay minerals such as kaolinite to produce $\mathrm{K}$-rich clays such as illite and authigenic K-feldspar (CARPENTER, 1978). NesBitT $(1980,1985)$ determined that formation waters from Mississippian-Pennsylvanian sandstone reservoirs in the basin are presently equilibrated with clay minerals, including illite. Greater $\mathrm{K}$ depletion in brines from Mississippian-Pennsylvanian strata compared with those from Silurian-Devonian reservoirs is consistent with the much larger proportion of siliciclastic rocks in the stratigraphic interval under study here.

- Diagenetic reactions with carbonate rocks seem to be responsible for the present concentration levels of divalent cations in Mississippian-Pennsylvanian formation waters. Calcium-bromide relations ( Fig. 8a) show an average 4-fold $\mathrm{Ca}$ enrichment over evaporated seawater whereas the $\mathrm{Mg}-\mathrm{Br}$ relations of Fig. $8 \mathrm{~b}$ illustrate a $\mathrm{Mg}$ depletion of about $53 \%$ in these brines (Table 3 ). The complementary diagenetic relations shown by these two cations strongly suggests that dolomitization of limestone is the responsible process (CAR. PENTER, 1978). Relations between $\mathrm{Sr}$ and $\mathrm{Br}$ (Fig. 8c) reveal very large increases in $\mathrm{Sr}$ concentrations relative to evaporated seawater (average approximately 12 -fold; Table 3 ); nearly 

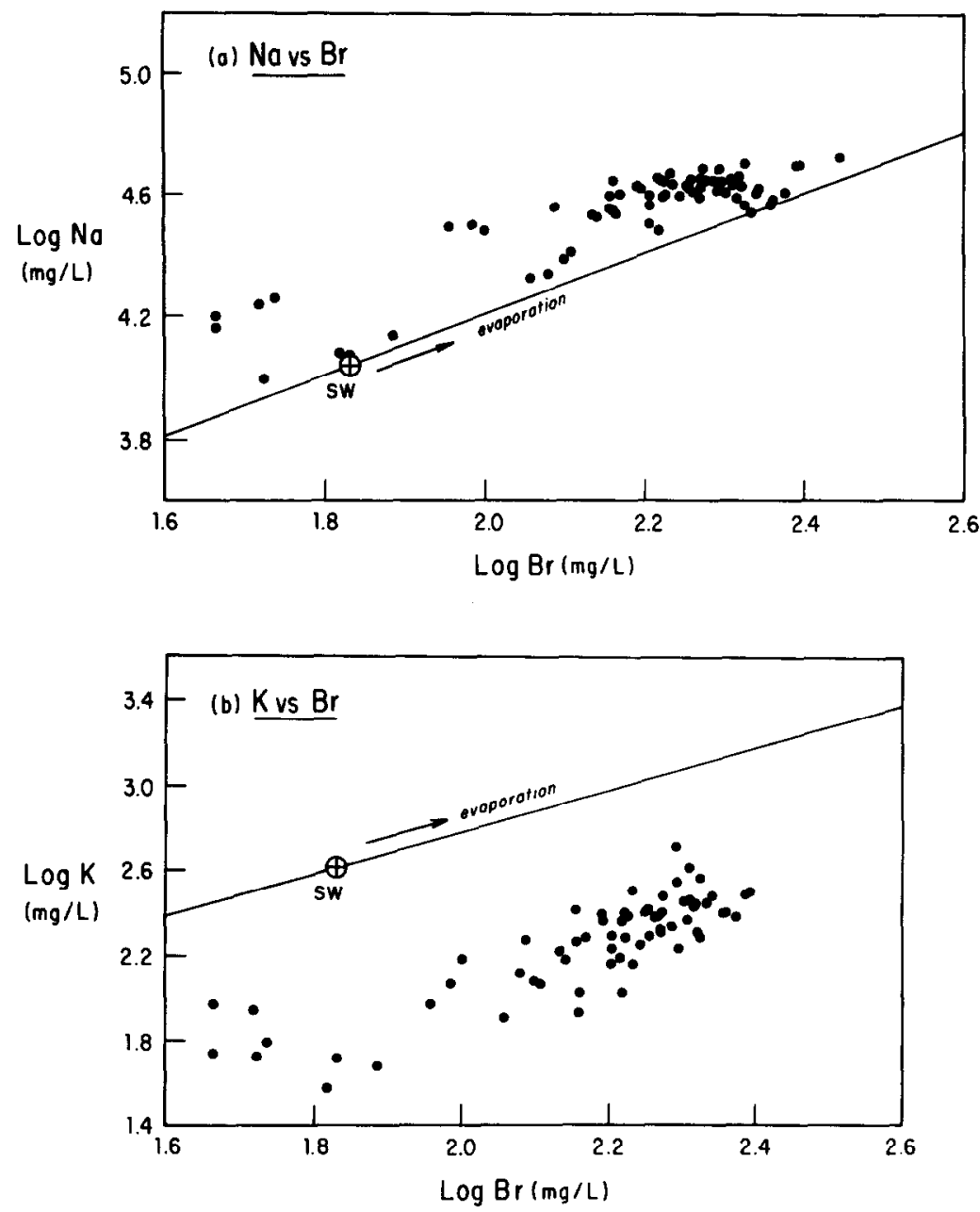

FIG. 7. (a) $\mathrm{Na}-\mathrm{Br}$ and (b) $\mathrm{K}-\mathrm{Br}$ relations in sixty-eight formation-water samples from Mississippian and Pennsylvanian reservoirs in the Illinois basin. Seawater evaporation trajectories from CARPENTER (1978); SW indicates seawater composition.

all the $\mathrm{Sr}$ in these formation waters seems to be a result of water-rock interactions, potentially from recrystallization and dolomitization of carbonate minerals. However, average $(\mathrm{Ca}$
$+\mathrm{Sr}$ ) enrichment exceeds $\mathrm{Mg}$ depletion on a molar basis by about $16 \%$, which suggests that dolomitization alone cannot explain the present concentration levels of these divalent cat-

\begin{tabular}{|c|c|c|c|c|c|}
\hline Lon & $\begin{array}{c}\text { Ion/Br } \\
\text { (Seawater)* }\end{array}$ & $\begin{array}{c}\text { Ion/Br } \\
\text { (Em. Waters) }\end{array}$ & $\begin{array}{c}\text { Enrichment } \\
\text { (Depletion) } \\
\text { Eactor** }\end{array}$ & $\begin{array}{c}\text { Dominant } \\
\text { Diagenetic } \\
\text { Process }\end{array}$ & $\begin{array}{c}\text { Enrichment } \\
\text { (Depletion) Factor } \\
\text { Silurian-Devonian } \\
\text { Em. Waters*** }\end{array}$ \\
\hline $\mathrm{Cl}^{-}$ & 292 & $427 \pm 76$ & 1.46 & halite dissolution & 1.00 \\
\hline $\mathrm{Na}^{+}$ & 163 & $233 \pm 47$ & 1.43 & $\begin{array}{l}\text { halite dissolution } \\
\text { reaction with clay minerals }\end{array}$ & 0.91 \\
\hline $\mathbf{K}^{+}$ & 6.12 & $1.24 \pm 0.37$ & 0.20 & reaction with clay minerals & 0.29 \\
\hline $\mathrm{Ca}^{2+}$ & 6.21 & $25.2 \pm 11.1$ & 4.06 & dolomitization & 3.49 \\
\hline $\mathrm{Mg}^{2+}$ & 19.5 & $9.20+2.20$ & 0.47 & dolomitization & 0.41 \\
\hline $\mathrm{Sr}^{2+}$ & 0.12 & $1.43 \pm 0.71$ & 11.9 & $\begin{array}{c}\mathrm{CaCO}_{3} \text { recrystallization } \\
\text { dolomitization }\end{array}$ & 11.0 \\
\hline
\end{tabular}

*Riley and Chester, 1971

**(Fm. Waters)/(Seawater)

***Stueber and Walter, 1991 

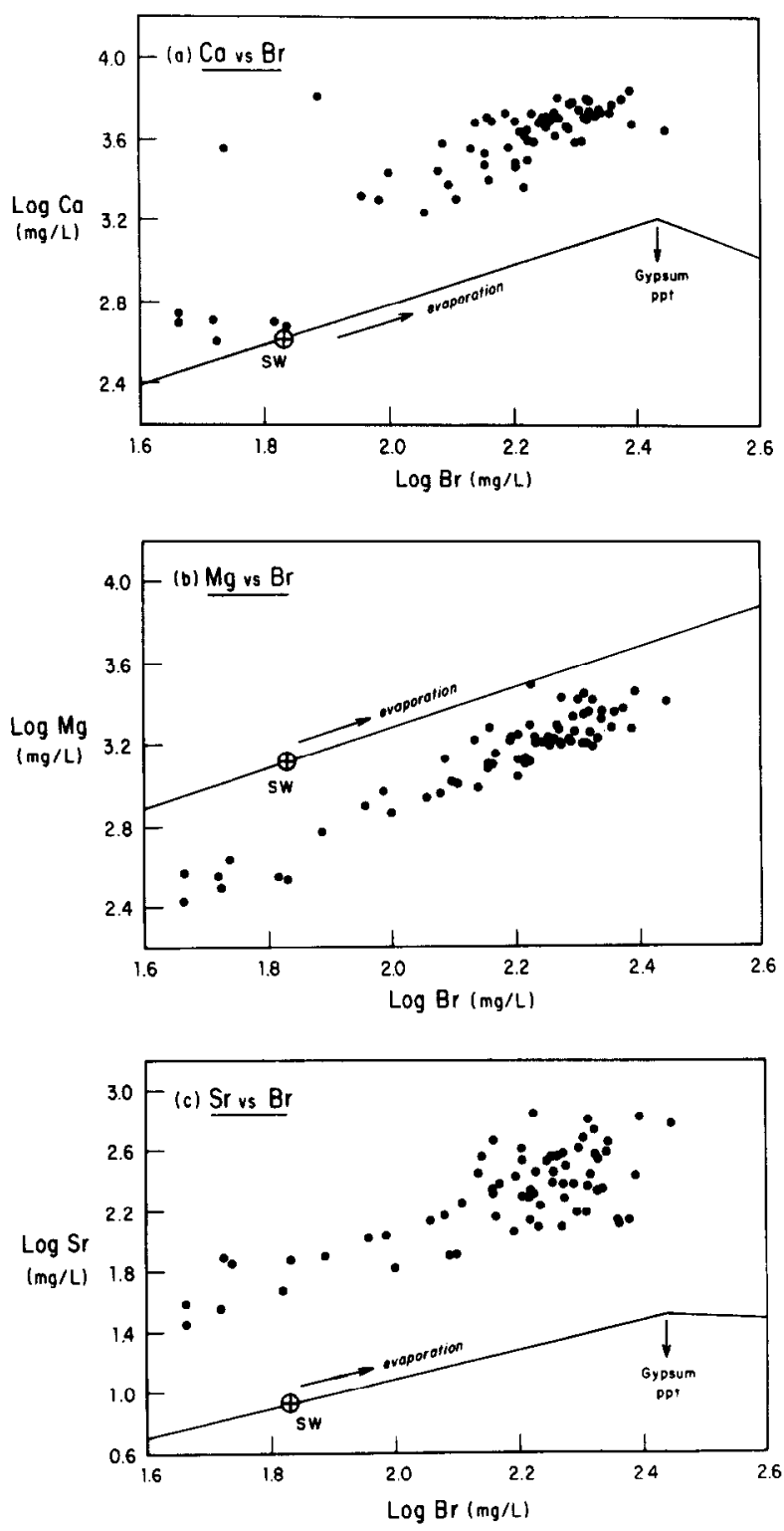

FIG. 8. (a) $\mathrm{Ca}-\mathrm{Br}$, (b) $\mathrm{Mg}-\mathrm{Br}$, and (c) $\mathrm{Sr}-\mathrm{Br}$ relations in sixty-eight formation-water samples from Mississippian and Pennsylvanian reservoirs in the Illinois basin. Seawater evaporation trajectories from CARPENTER (1978); SW indicates seawater composition.

ions. It is possible that albitization and feldspar dissolution could also have released $\mathrm{Ca}$ and $\mathrm{Sr}$ but large uncertainties in average cation $/ \mathrm{Br}$ ratios (Table 3 ) indicate that further speculation on the balance of these diagenetic reactions is not warranted.

Cation-bromide relations in formation waters from Mississippian-Pennsylvanian rescrvoirs, with the exception of $\mathrm{Na}$ $\mathrm{Br}$, are very similar to those found in Silurian-Devonian brines (Table 3 ). Thus it appears that the same diagenetic processes have established the present chemical composition of waters in both of these major segments of the Illinois basin stratigraphic section, with the important exception of halite dissolution. Mississippian-Pennsylvanian brines have been clearly distinguished by elevated $\mathrm{Cl} / \mathrm{Br}$ and $\mathrm{Na} / \mathrm{Br}$ ratios as a result of this particular water-rock interaction.

\section{ISOTOPE RELATIONS}

\section{Strontium Isotope Systematics}

Strontium isotope systematics can provide useful information about formation-water evolution in the subsurface. Brine ${ }^{87} \mathrm{Sr} /{ }^{86} \mathrm{Sr}$ ratios serve as tracers of water-rock interactions and when related to $\mathrm{Sr}$ concentrations, the system can be used to investigate mixing events among formation waters. A reconnaissance of ${ }^{87} \mathrm{Sr} /{ }^{86} \mathrm{Sr}$ in waters from Ordovician through Pennsylvanian strata in the Illinois basin (STUEBER et al., 1987) revealed a range of ratios from 0.7079 to 0.7108 ; with just a few exceptions (samples from Ste. Genevieve Limestone reservoirs) these brines were more radiogenic than corresponding Paleozoic seawater values. The study also involved a more intensive sampling and analysis of ${ }^{87} \mathrm{Sr} /{ }^{86} \mathrm{Sr}$ ratios in waters from Silurian-Devonian carbonate strata, which are summarized in histogram form in Fig. 9 along with some additional analyses of Silurian-Devonian brines from STUEBER and WALTER (1991). When these data are compared with ${ }^{87} \mathrm{Sr} /{ }^{86} \mathrm{Sr}$ ratios of waters from MississippianPennsylvanian strata reported here (Table 2; Fig. 9), a clear distinction between the $\mathrm{Sr}$ isotopic character of the fluids in these two major segments of the stratigraphic column is observed. Whereas the distributions of $\mathrm{Sr}$ isotope ratios in Silurian-Devonian carbonate waters and in MississippianPennsylvanian sandstone waters are comparable, formation waters from the stratigraphically intervening Ste. Genevieve Limestone are distinctly less radiogenic and include some samples with ${ }^{87} \mathrm{Sr} /{ }^{86} \mathrm{Sr}$ essentially equivalent to seawater at the time of reservoir rock deposition.

The New Albany Shale Group (Fig. 1 ) represents a potential source of the radiogenic ${ }^{87} \mathrm{Sr}$ in these brines because shales contain inherited siliciclastic minerals. Furthermore, the New Albany shales have been identified as the source of petroleum in Silurian-Devonian and Mississippian-Pennsylvanian reservoirs (HATCH et al., 1991) indicating that fluid migration from the New Albany into these reservoirs has taken place. We carried out chemical and $\mathrm{Sr}$ isotopic analyses of ten New Albany shale core samples from widely separated locations in Illinois in order to characterize this important stratigraphic unit with respect to the geochemical data reported in the formation waters. The ${ }^{87} \mathrm{Sr} /{ }^{86} \mathrm{Sr}$ ratios of these whole-rock samples (Table 4) are quite variable but all are significantly more radiogenic than the range of values in the brines (Fig. 9). Leaching experiments performed on three of the shale samples (STUEBER et al., 1987) showed that the loosely bound $\mathrm{Sr}$ in clay minerals has an isotopic composition in the range $0.7102-0.7129$, comparable with values found in the most radiogenic formation waters.

Although New Albany shales are a likely source of radiogenic ${ }^{87} \mathrm{Sr}$ in brines from stratigraphically subjacent Silurian and Devonian carbonate reservoirs, the distribution of ${ }^{87} \mathrm{Sr} /$ ${ }^{86} \mathrm{Sr}$ ratios in waters from Mississippian and Pennsylvanian strata (Fig. 9) suggests that alternative sources should also be considered in the case of these fluids. Mississippian and Pennsylvanian sandstone waters are more radiogenic than waters from underlying Ste. Genevieve Limestone reservoirs, an unlikely result of upward migration of a ${ }^{87} \mathrm{Sr}$-enriched fluid from New Albany shales. Formation waters in Mississippian-Pennsylvanian strata likely acquired radiogenic ${ }^{87} \mathrm{Sr}$ 


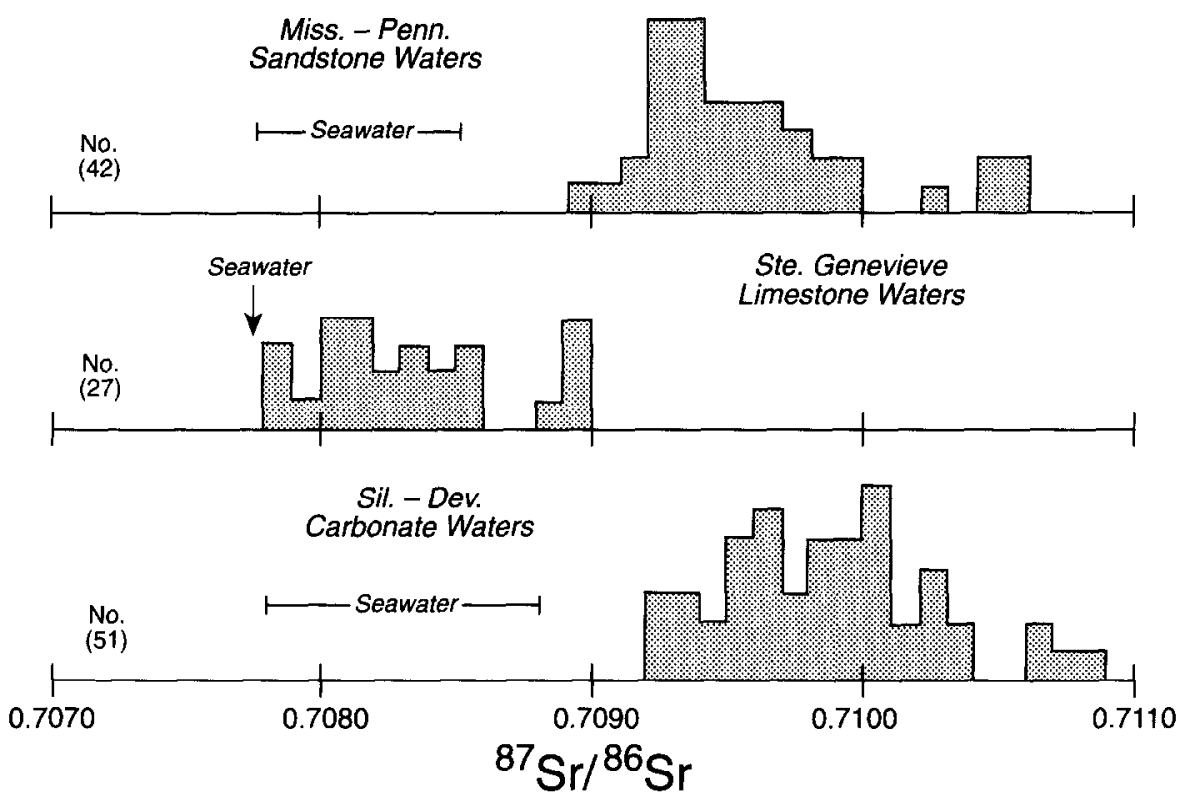

FIG. 9. Distribution of ${ }^{87} \mathrm{Sr} /{ }^{86} \mathrm{Sr}$ ratios in formation waters from three stratigraphic intervals in the Illinois basin. Data are from STUEBER et al. (1987), STUEBER and WALTER (1991), and this study. Seawater values are from BRAND (1991) and from BURKE et al. (1982).

through localized water-rock interactions with siliciclastic units found in that portion of the stratigraphic section.

Further insight into the $\mathrm{Sr}$ isotopic evolution of these formation waters can be obtained from the relation between ${ }^{87} \mathrm{Sr} /{ }^{86} \mathrm{Sr}$ ratios and $\mathrm{Sr}$ concentrations. When the data for Silurian-Devonian formation waters are plotted within the coordinates ${ }^{87} \mathrm{Sr} /{ }^{86} \mathrm{Sr}$ vs. 1/ $\mathrm{Sr}$ to investigate two-component mixing (FAURE, 1986), a linear pattern with a positive slope is observed (Fig. 10a). STUEBER and WALTER (1991) noted that scatter of data points within the general trend probably results from the effects of local precipitation of sulfate minerals on $\mathrm{Sr}$ concentrations, suggested by chemical and isotopic analyses of six samples from closely spaced wells in a single oil field (Fig. 10a). They interpreted the positive correlation between ${ }^{87} \mathrm{Sr} /{ }^{86} \mathrm{Sr}$ and $1 / \mathrm{Sr}$ in all Silurian-Devonian brines as the result of mixing between a ${ }^{87} \mathrm{Sr}$-enriched fluid from New Albany shales and interstitial water containing marine
Sr derived from carbonate diagenesis in Silurian-Devonian reservoirs. This interpretation is supported by the association of the formation waters with petroleum accumulations derived from the stratigraphically adjacent New Albany shales (HATCH et al., 1991) and by the need for a major source of radiogenic ${ }^{87} \mathrm{Sr}$, which is not obviously present in the SilurianDevonian carbonate strata.

Formation waters from Mississippian and Pennsylvanian strata (Fig. 10b,c) show completely unsystematic relations between ${ }^{87} \mathrm{Sr} /{ }^{86} \mathrm{Sr}$ and $1 / \mathrm{Sr}$, suggesting that the $\mathrm{Sr}$ isotopic system in waters from this segment of the stratigraphic section has evolved in a different manner. Ste. Genevieve Limestone waters (Fig. 10b) are distinctly less radiogenic than SilurianDevonian carbonate waters; a few of the samples show ${ }^{87} \mathrm{Sr}$ / ${ }^{86} \mathrm{Sr}$ in virtual agreement with seawater at the time these rocks were deposited (0.70773; BRAND, 1991). The absence of any correlation between ${ }^{87} \mathrm{Sr} /{ }^{86} \mathrm{Sr}$ and $1 / \mathrm{Sr}$ in Ste. Genevieve

Table 4. Analyses of whole-rock samples of New Albany shales*

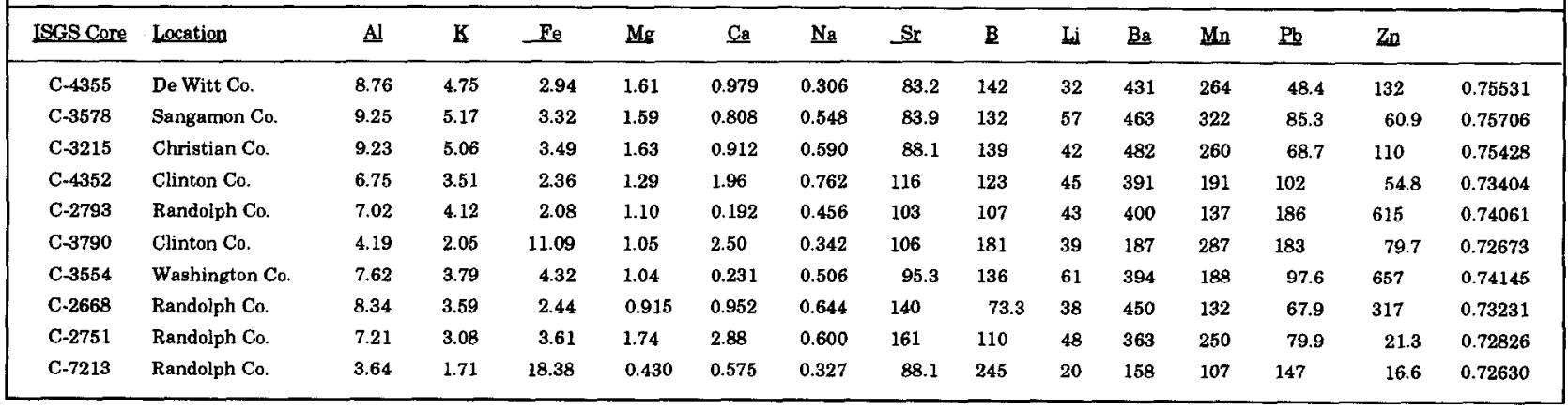



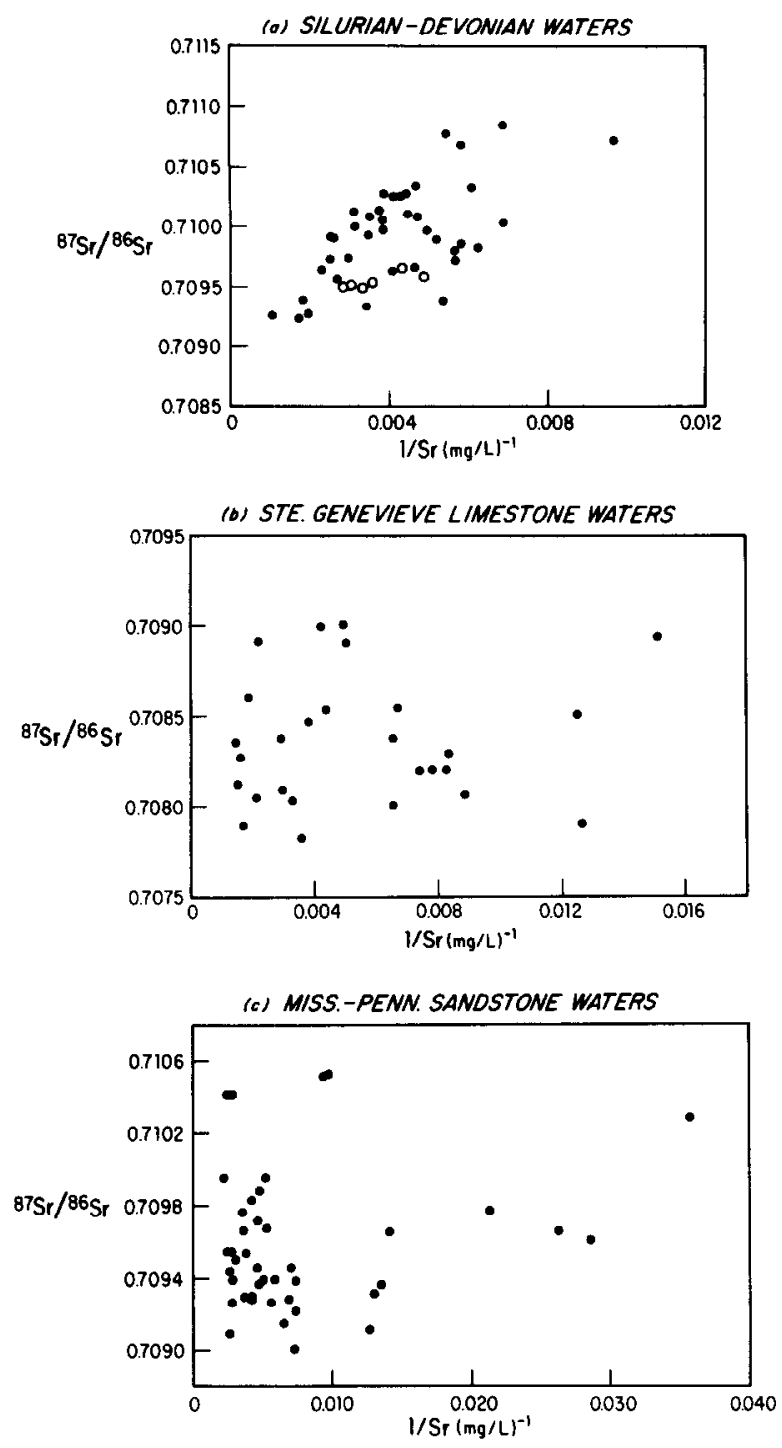

FIG. $10 .{ }^{87} \mathrm{Sr} /{ }^{86} \mathrm{Sr}$ vs. $1 / \mathrm{Sr}$ relations in formation waters from (a) Silurian-Devonian carbonate reservoirs (STUEBER and WALTER, 1991; open circles represent samples from Bartelso E field), (b) Ste. Genevieve carbonate reservoirs, and (c) Mississippian-Pennsylvanian sandstone reservoirs.

waters suggests that the relatively small enrichment in radiogenic ${ }^{87} \mathrm{Sr}$ may be due to water-rock interactions with minor intercalated argillaceous material.

The more radiogenic Mississippian-Pennsylvanian sandstone waters (Fig. 10c) are from a stratigraphic interval composed predominantly of shales and sandstones (Fig. 2), providing ample sources of radiogenic ${ }^{87} \mathrm{Sr}$ for the brines through water-rock interactions. STUEBER et al. (1987) reported highly radiogenic whole-rock ${ }^{87} \mathrm{Sr} /{ }^{86} \mathrm{Sr}$ ratios for siliciclastic strata in this interval. Another factor to be considered is the significant variability in seawater ${ }^{87} \mathrm{Sr} /{ }^{86} \mathrm{Sr}$ reported for latest Mississippian and Pennsylvanian time. BRAND (1991) presented a high-resolution curve of seawater ${ }^{87} \mathrm{Sr} /{ }^{86} \mathrm{Sr}$ for the Carboniferous which showed a range of values between 0.7078 and 0.7085 during the time of deposition of the Mississippian-Pennsylvanian sandstone reservoirs. The contrast in $\mathrm{Sr}$ isotope systematics shown by fluids from Silurian-Devonian and Mississippian-Pennsylvanian reservoirs marks a second fundamental geochemical distinction between formation waters from these two major segments of the Illinois basin stratigraphic column.

\section{Intra-Field Strontium Isotope Relations}

Regional investigations of $\mathrm{Sr}$ isotope systematics in formation waters from a particular stratigraphic unit within a sedimentary basin commonly involve only one or two water samples from any individual oil field in order to maximize geographic extent of sample distribution. In the interpretation of ${ }^{87} \mathrm{Sr} /{ }^{86} \mathrm{Sr}$ vs. $1 / \mathrm{Sr}$ relations such as those in Fig. 10 it is also important to evaluate geochemical processes that may be occurring in the reservoir rock on a local basis and to assess the representative nature of any individual sample. As a part of the present study we have examined intra-field variability in chemical and $\mathrm{Sr}$ isotopic composition of formation waters by analyzing six samples from closely spaced wells producing from a small lens of Aux Vases sandstone in Thompsonville $\mathrm{N}$ field (Table 5). Data from a similar study involving waters from a Silurian carbonate reef (STUEBER and WALTER, 1991 ) are included in Table 5 for comparison. Thompsonville $\mathrm{N}$ brines show a high degree of chemical uniformity for all major and minor elements, and even for trace elements such as $\mathrm{B}, \mathrm{Li}$, and $\mathrm{Ba}$. Formation waters from Bartelso $\mathrm{E}$ field are uniform in most major and minor element concentrations, with the exception of $\mathrm{Ca}, \mathrm{Sr}$, and $\mathrm{SO}_{4}$.

Brine ${ }^{87} \mathrm{Sr} /{ }^{86} \mathrm{Sr}$ ratios are essentially constant within each of these oil fields (Table 5), a feature commonly observed in other fields when more than one sample has been analyzed. The similarity in $\mathrm{Sr}$ isotopic composition between samples from the two fields is coincidental. Whereas $\mathrm{Sr}$ concentrations in the Aux Vases sandstone waters of Thompsonville $\mathrm{N}$ are quite uniform, Sr ranges from 204 to $345 \mathrm{mg} / \mathrm{L}$ in the Silurian carbonate brines from Bartelso E. STUEBER and WALTER (1991) suggested that precipitation of gypsum or anhydrite in the carbonate reservoir rock may be responsible for the variable $\mathrm{Ca}, \mathrm{Sr}$, and $\mathrm{SO}_{4}$ levels in the Bartelso $\mathrm{E}$ samples, and that such local diagenetic processes may account for lateral separation of data points in ${ }^{87} \mathrm{Sr} /{ }^{86} \mathrm{Sr}$ vs. $1 / \mathrm{Sr}$ diagrams such as Fig. 10a. When the $\mathrm{Sr}$ isotopic system is employed to investigate two-component fluid mixing relations they advocated collection of multiple samples from individual oil fields and use of only the sample with maximum Sr concentration from each field in order to minimize the possible effects of post-mixing precipitation. Data for Thompsonville $\mathrm{N}$ sandstone waters (Table 5) suggest that hydrologic continuity within such reservoirs is sufficient to re-establish chemical uniformity in formation waters after diagenetic reactions occur. Thus data for single samples from individual oil fields (Table 2; Fig. 10c) may be representative of waters throughout the local sandstone reservoirs.

\section{Mineral Saturation Controls on Strontium Isotope Systematics}

Local diagenetic processes were further investigated by considering potential equilibrium relations between forma- 


\begin{tabular}{|c|c|c|c|c|c|c|c|c|c|c|c|c|c|c|c|}
\hline Sample & $\mathrm{Na}$ & Ca & $\mathrm{Mg}$ & $\underline{\mathbf{K}}$ & $\underline{\mathrm{Sr}}$ & Cl & $\mathrm{Br}$ & $\underline{\mathrm{SO4}}$ & $\underline{\mathbf{S i}}$ & $\underline{\mathbf{B}}$ & $\underline{\underline{\mathbf{L i}}}$ & $\mathrm{Ba}$ & $\underline{\mathrm{Fe}}$ & $\underline{\mathrm{Mn}}$ & ${ }^{87} \mathrm{Sr} /{ }^{66} \mathrm{~S}_{\mathrm{r}}$ \\
\hline \multicolumn{16}{|c|}{ THOMPSONVILLE N FIELD - Aux Vases Ss } \\
\hline 245 & 42500 & 6290 & 1790 & 205 & 365 & 81800 & 209 & 702 & 6.35 & 3.74 & 9.46 & 0.68 & 7.18 & 0.46 & 0.70954 \\
\hline 246 & 42900 & 6350 & 1800 & 198 & 359 & 82350 & 208 & 641 & 6.67 & 3.68 & 9.23 & 0.96 & 1.55 & 0.54 & 0.70945 \\
\hline 247 & 41900 & 6450 & 1790 & 198 & 365 & 81240 & 204 & 785 & 6.00 & 3.81 & 9.76 & 0.62 & 24.8 & 0.57 & 0.70942 \\
\hline 248 & 41300 & 6490 & 1690 & 189 & 351 & 81550 & 196 & 814 & 8.95 & 3.50 & 9.74 & 0.60 & 24.0 & 0.58 & 0.70931 \\
\hline 249 & 42300 & 6390 & 1760 & 199 & 348 & 82970 & 207 & 815 & 3.11 & 3.25 & 9.42 & 0.60 & 27.2 & 0.99 & 0.70947 \\
\hline 250 & 42000 & 6300 & 1770 & 196 & 356 & 81860 & 204 & 805 & 5.34 & 3.56 & 9.37 & 0.60 & 24.5 & 0.60 & 0.70947 \\
\hline \multicolumn{16}{|c|}{ BARTELSO E FIELD - Moccasin Springs Ls } \\
\hline 256 & 36030 & 6970 & 2490 & 621 & 204 & 75500 & 255 & 1367 & 7.11 & 11.3 & 20.7 & 0.07 & NA & NA & 0.70958 \\
\hline 257 & 36100 & 6520 & 2420 & 608 & 276 & 75400 & 259 & 687 & 6.16 & 11.0 & 17.0 & 0.35 & NA & NA & 0.70954 \\
\hline 258 & 36950 & 6380 & 2440 & 503 & 328 & 75600 & 258 & 693 & 6.45 & 9.68 & 19.7 & 0.14 & NA & NA & 0.70951 \\
\hline 259 & 37400 & 6810 & 2440 & 663 & 228 & 76600 & 262 & 1133 & 6.43 & 10.7 & 15.1 & 0.09 & NA & NA & 0.70964 \\
\hline 260 & 37150 & 6390 & 2430 & 632 & 345 & 75800 & 252 & 444 & 6.39 & 12.1 & 15.0 & 0.41 & NA & NA & 0.70950 \\
\hline 262 & 34250 & 9090 & 2380 & 629 & 297 & 75500 & 230 & 93 & 11.7 & 8.96 & 15.8 & 1.19 & $\mathrm{NA}$ & $\mathrm{NA}$ & 0.70948 \\
\hline
\end{tabular}

$\mathrm{NA}=$ not analyzed

tion waters and minerals in the reservoir rocks. The computer code SOLMINEQ.88 (KHARAK A et al., 1988), which offers the option of Pitzer's parameters to calculate ion activities, was employed to determine degree of mineral saturation with respect to several mineral species. The reactions investigated are:

$\mathrm{CaSO}_{4}=\mathrm{Ca}^{2+}+\mathrm{SO}_{4}^{2-}$

(anhydrite dissolution/precipitation)

$\mathrm{BaSO}_{4}=\mathrm{Ba}^{2+}+\mathrm{SO}_{4}^{2-}$

(barite dissolution/precipitation)

$\mathrm{SrSO}_{4}=\mathrm{Sr}^{2+}+\mathrm{SO}_{4}^{2-}$

(celestite dissolution / precipitation)

$2 \mathrm{CaCO}_{3}+\mathrm{Mg}^{2+}=\mathrm{CaMg}\left(\mathrm{CO}_{3}\right)_{2}+\mathrm{Ca}^{2+}$

(replacement of calcite by disordered dolomite).

For these reactions, a saturation index (S.I.) of 1 indicates equilibrium; the log S.I. value at equilibrium is therefore equal to zero. Given analytical, theoretical, and computational uncertainties, the $\log$ S.I. value is probably reliable only within $\pm 0.2 \log$ units for these minerals. The evaluations are limited by lack of $\mathrm{pH}$ and carbonate alkalinity data for our samples, but the calculated ion activities for $\mathrm{Ca}^{2+}, \mathrm{Mg}^{2+}, \mathrm{Ba}^{2+}, \mathrm{Sr}^{2+}$, and $\mathrm{SO}_{4}^{2-}$ are not sensitive to changes in values of $\mathrm{pH}$ or alkalinity over the ranges reported by MEENTS et al. (1952) for Illinois basin brines. Temperatures and pressures of formation waters were estimated from reservoir depths and appropriate gradients.

Results of equilibrium modeling indicate that the Aux Vases sandstone waters from Thompsonville $\mathbf{N}$ field are undersaturated ( $\log$ S.I. generally -0.4 or less) with respect to anhydrite but near equilibrium with respect to celestite, barite, and disordered dolomite ( $\log$ S.I. generally within $\pm 0.2 \log$ units). Formation waters from the carbonate reservoir at Bartclso $E$ are undersaturated with respect to both anhydrite and celestite, but near equilibrium with respect to barite and disordered dolomite. An important observation from our data is that brines from Silurian-Devonian carbonate reservoirs in general appear to be undersaturated with respect to celestite and that their present $\mathrm{Sr}$ concentrations are therefore not controlled by mineral equilibrium. Thus evidence of twocomponent fluid mixing in the geologic past has been preserved (Fig. 10a), although Sr concentrations have been modified to some degree by earlier mineral precipitation in the local reservoir rocks. On the other hand, our data show that $\mathrm{Sr}$ and $\mathrm{SO}_{4}$ concentrations in formation waters in Mississippian Ste. Genevieve and Aux Vases reservoirs throughout the basin are generally well correlated as illustrated in Fig. 11. Thus the present $\mathrm{Sr}$ concentrations in these waters are controlled by celestite equilibration and if two-component mixing relations existed in the past they are now obscurcd (Fig. 10b,c).

\section{Integration of Chemical and Strontium Isotope Data}

In the absence of two-component mixing relations among Mississippian-Pennsylvanian formation waters (Fig. 10b,c), we investigated the possibility that these brines acquired radiogenic ${ }^{87} \mathrm{Sr}$ through water-rock interactions with the abundant detrital sediments in that portion of the stratigraphic section. If this mechanism is responsible for evolution of the Sr isotopic system in these waters, supporting evidence might be found in rclations between ${ }^{87} \mathrm{Sr} /{ }^{86} \mathrm{Sr}$ and other chemical species that may have participated in the water-rock interactions. When ${ }^{87} \mathrm{Sr} /{ }^{86} \mathrm{Sr}$ ratios are plotted vs. concentrations of major, minor, and trace elements in the brines (Table 2), the only indications of correlation are observed for $\mathrm{B}, \mathrm{Li}$, and $\mathrm{Mg}$ concentrations (Fig. 12). Although there is considerable scatter among the data points, each of these plots shows a general trend with a negative slope. Normalization of element concentrations to $\mathrm{Cl}$ or $\mathrm{Br}$ concentrations to compensate for meteoric water dilution does not significantly improve definition of the trends.

The inverse correlations between ${ }^{87} \mathrm{Sr} /{ }^{86} \mathrm{Sr}$ and $\mathrm{B}, \mathrm{Li}$, and $\mathrm{Mg}$ in Fig. 12 suggest that these formation waters may have interacted with clay minerals in the Mississippian-Pennsylvanian strata, acquiring loosely bound radiogenic ${ }^{87} \mathrm{Sr}$ while 


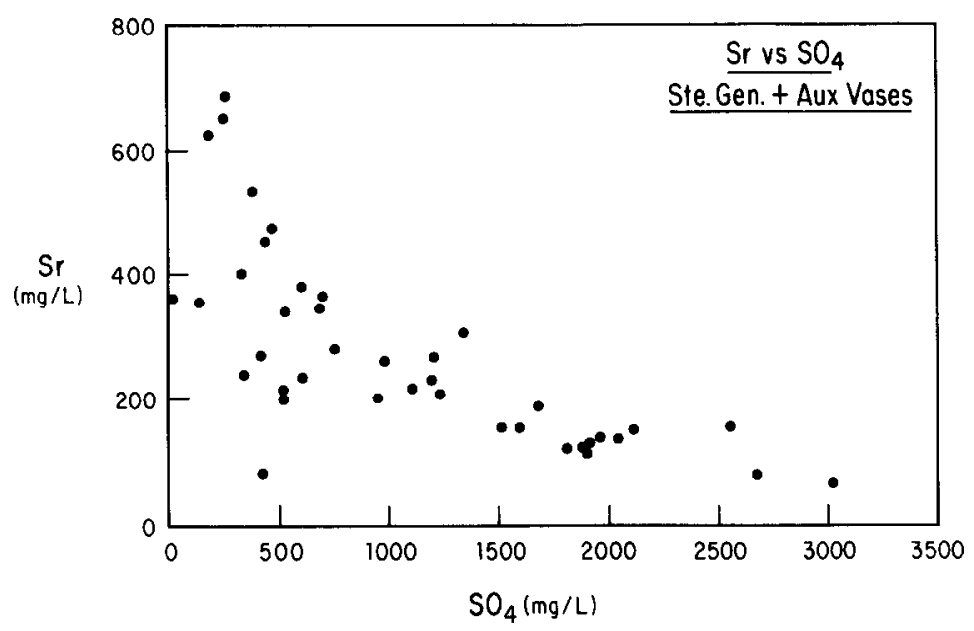

FIG. 11. Sr vs. $\mathrm{SO}_{4}$ in formation waters from Ste. Genevieve carbonate and Aux Vases sandstone reservoirs.

losing B, Li, and Mg to clay minerals. Scatter of data points within the trends probably reflects variable degrees of waterclay interaction as a function of brine migration history. Boron adsorption onto clay minerals is well documented (e.g., SCHWARCZ et al., 1969; VENGOSH et al., 1991a) and lithium is associated with clay minerals (SEYFRIED et al., 1984) although the affinity of Li for clays has been explained by its ability to occupy octahedral sites rather than by adsorption reactions (STOFFYN-EgLI and MACKENZIE, 1984).

Present B concentration levels in Mississippian-Pennsylvanian formation waters (Table 2) are lower than those expected for the evaporation of modern seawater short of halite precipitation, presumably because of diagenetic depletion through adsorption on clays. However, high B concentrations in brines are frequently attributed to diagenesis of organic matter or petroleum (COLLINS, 1975); HIRNER et al. (1990) demonstrated a B enrichment of up to nearly three orders of magnitude in the mobile organic fractions of sediments, including oil shales. Thus, B in Illinois basin brines could be related to fluid migration from New Albany shales, which presently contain B at concentration levels (Table 4) comparable with the world-wide average of $130 \mathrm{ppm}$ for mudstones (HARDER, 1974). Lithium concentration levels in Mississippian-Pennsylvanian waters (Table 2) range up to nearly $20 \mathrm{mg} / \mathrm{L}$, more than an order of magnitude greater than the concentration reached by seawater evaporation to halite saturation. Such $\mathrm{Li}$ contents are typically found in brines from other sedimentary basins (HEIER and BILLINGS, 1969; CoLLINS, 1975), and may be the result of aluminosilicate mineral-water reactions in which $\mathrm{Li}$ behaves as an incompatible element (MOLDOVANYI and WALTER, 1992). New Albany shales show Li concentrations (Table 4) similar to the world-wide average of $76 \mathrm{ppm}$ for marine mudstones (HEIER and BILLINGS, 1969).

Stratigraphic relations between the Ste. Genevieve Limestone and the Aux Vases Sandstone provide further evidence that water-rock interactions have controlled $\mathrm{Sr}$ isotope evolution in formation waters from these strata. These two formations represent the transition from dominantly carbonate rocks of the Valmeyeran Series to dominantly siliciclastic rocks in the Chesterian Series (Fig. 2). Much of the Aux Vases in the Mississippi River Valley and western portions of the Illinois basin is equivalent in age to the upper part of the Ste. Genevieve in central and eastern portions of the basin (CluFF and LineBACK, 1981), as shown in Fig. 13a. As a result of this facies relationship analyzed formation waters from the two units, which show distinctly different ${ }^{87} \mathrm{Sr} /{ }^{86} \mathrm{Sr}$ ranges, have been produced from the same depth interval (Fig. 13b). If the strontium isotopic character of Mississippian-Pennsylvanian brines has been established by a ${ }^{87} \mathrm{Sr}-$ enriched fluid ascending from New Albany shales, it seems reasonable to assume that the isotopic composition of fluids entering the Ste. Genevieve carbonate and Aux Vases sandstone reservoirs was fairly uniform because the fluids had experienced comparable migration histories. The present distinctly more radiogenic nature of Aux Vases formation waters (Fig. 13b) strongly suggests that the enrichment in ${ }^{87} \mathrm{Sr}$ occurred through water-rock interactions with the dominant siliciclastic minerals in that reservoir rock. The possibility remains that the smaller increment of radiogenic ${ }^{87} \mathrm{Sr}$ found in Ste. Genevieve carbonate waters, as well as a portion of the ${ }^{87} \mathrm{Sr}$ enrichment in Aux Vases sandstone waters, was introduced by fluid migration from below. However, the weight of evidence revealed in this study supports water-rock interaction as the dominant control on strontium isotope ratios in brines from Mississippian and Pennsylvanian strata in the Illinois basin.

\section{Boron Isotope Controls on Solute Sources}

The boron isotopic systematics of seawater and surficial brines are beginning to be understood and may provide additional constraints in elucidating the origin of solutes in subsurface brines. Boron isotopic compositions of selected formation waters from the Mississippian-Pennsylvanian and Silurian-Devonian segments of the Illinois basin stratigraphic column are presented in Table 6 , along with other related compositional data. Modern seawater has a boron isotopic composition of about $+40 \%$ (SPIVACK et al., 1987). All of the analyzed Illinois basin brines have isotopic compositions 

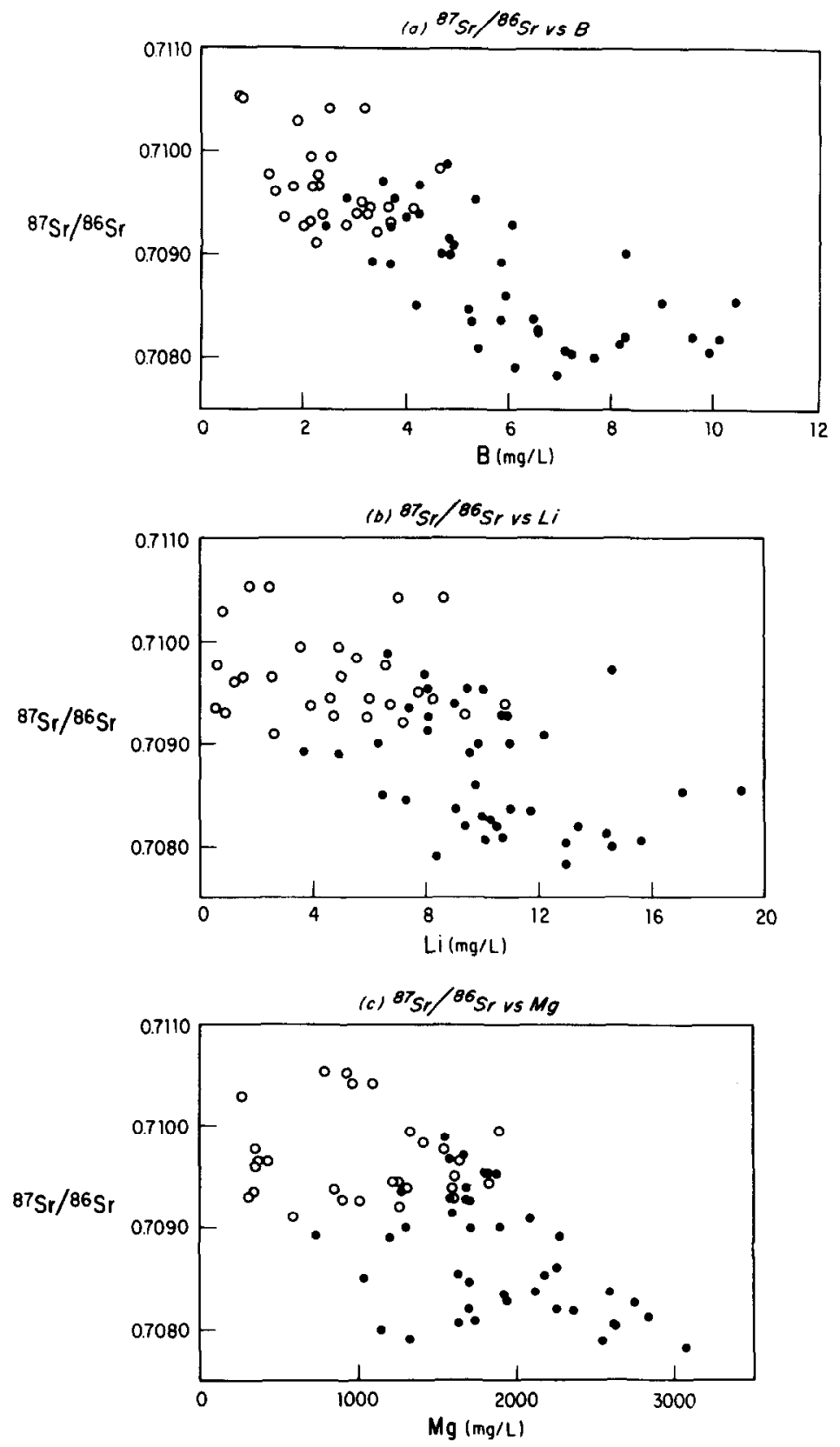

FIG. 12. Relations between ${ }^{87} \mathrm{Sr} /{ }^{86} \mathrm{Sr}$ and (a) boron, (b) lithium, and (c) magnesium in formation waters from Mississippian and Pennsylvanian reservoirs in the Illinois basin. Solid points represent Ste. Genevieve and Aux Vases samples whereas open circles indicate samples from Chesterian and Pennsylvanian clastic reservoirs.

depleted in ${ }^{11} \mathrm{~B}$ relative to seawater, with values ranging from +39 to $+18 \%$.

Boron adsorbed onto clay minerals is isotopically light relative to seawater (SPIVACK et al., 1987; VENGOSH et al., $1991 \mathrm{a}, \mathrm{b})$. The uptakc of $\mathbf{B}$ onto clays from seawater in a closed system would thus produce boron-depleted fluids with an increased $\delta^{11} \mathbf{B}$ value. Release of $\mathbf{B}$ from clays during later diagenesis would increase the ${ }^{10} \mathrm{~B}$ in solution and lower the $\delta^{11} \mathrm{~B}$ value. Although brines with boron isotopic values more positive than seawater have been reported from the Dead Sea (VENGOSH et al., 1991a) and from Australian salt lakes of marine parentage (VENGOSH et al., 1991b), the data for sed- imentary basin brines available at this time generally are isotopically depleted relative to modern seawater. MACPHERSON and LAND (1989) reported boron isotopic compositions for Gulf Coast basin waters which for the most part range between +40 and $+15 \%$, similar to the range found in the Illinois basin waters (Table 6). Isotopically light $B$ could be derived from clay minerals or from other crustal B sources ( $M \wedge C$ PHERSON and LAND, 1989; VENGOSH et al., 1991b).

The boron isotopic data for Illinois basin brines are shown as histograms relative to reservoir-rock age and lithology in Fig. 14. Based on the boron isotopic compositions alone, it would appear that Pennsylvanian sandstone waters and Si- 

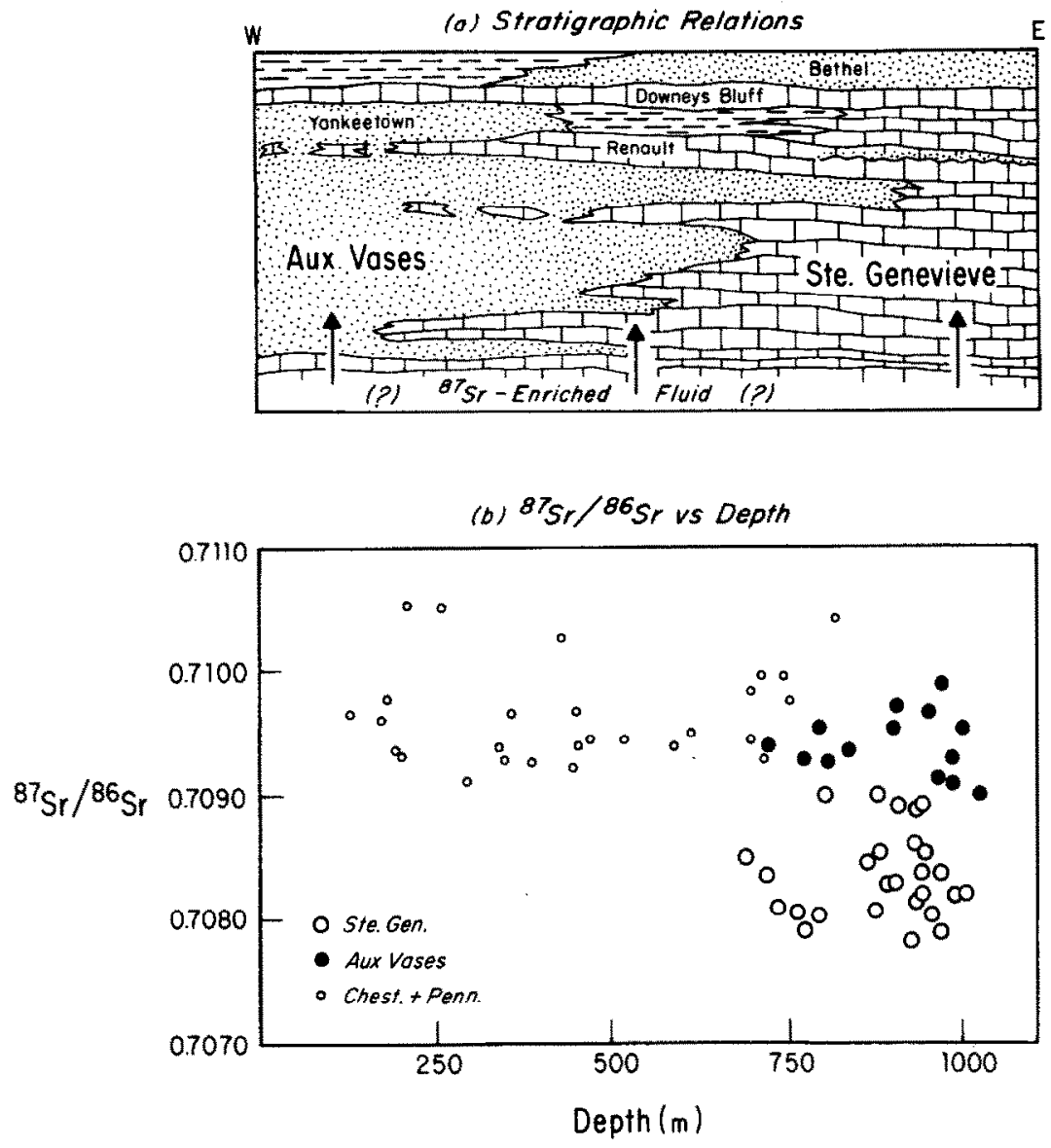

FIG. 13. (a) Stratigraphic relations between the Aux Vases Sandstone and upper beds of the Ste. Genevieve Limestone from west to east across the Illinois basin (after CLUFF and LINEBACK, 1981). (b) ${ }^{87} \mathrm{Sr} /{ }^{86} \mathrm{Sr}$ vs. production depth of formation waters from Mississippian and Pennsylvanian reservoirs.

lurian-Devonian carbonate waters have been most significantly affected by the introduction of isotopically light $B$. Also, it is clear that the Silurian-Devonian carbonate waters are distinctly different in their isotopic composition from the Mississippian carbonate waters. Thus the discontinuity in the strontium isotopic composition between Silurian-Devonian and Mississippian carbonate waters (Fig. 9) is also found in their boron isotopic compositions.

The boron isotopic compositions of Illinois basin waters have been plotted vs. $\mathrm{Br} / \mathrm{B}$ ratios and strontium isotopic compositions in Fig. 15. The $\mathrm{Br} / \mathrm{B}$ ratios are used to circumvent the effect of meteoric water dilution on the $B$ contents of the samples. All the brines are depleted in terms of both their isotopic composition and their normalized B content relative to modern seawater (Fig. 15a). Although there is considerable scatter of data points in Fig. 15b, the boron and strontium isotopic discontinuity between Silurian-Devonian and Mississippian carbonate waters is evident. Silurian-Devonian brines are more radiogenic in ${ }^{87} \mathrm{Sr}$ and more depleted in ${ }^{11} \mathrm{~B}$ than Mississippian brines, suggesting that clay mineral alteration was an important source of Sr and B in the SilurianDevonian waters. This is consistent with our interpretation that radiogenic ${ }^{87} \mathrm{Sr}$ in Silurian-Devonian formation waters has been introduced by mixing with a fluid from New Albany shales. Additional interpretive insights from these boron iso- topic data will await brine analyses from other sedimentary basins as well as an improved understanding of the boron isotopic evolution of ancient seawater.

\section{DISCUSSION}

Knowledge of formation-water origin and chemical evolution provides information for interpreting paleohydrologic flow patterns which can be compared with hydrogeologic models. The distinctly different geochemical characteristics of Silurian-Devonian and Mississippian-Pennsylvanian formation waters, in terms of $\mathrm{Cl}-\mathrm{Br}-\mathrm{Na}$ and $\mathrm{Sr}$ isotope systematics, may have resulted in part from Illinois basin hydrostratigraphy and deep groundwater flow regimes. The DevonianMississippian New Albany Shale Group (Fig. 1) probably served as a regional aquitard (BETHKE et al., 1991), restricting communication between waters in Silurian-Devonian and Mississippian-Pennsylvanian strata as they evolved chemically under the influence of different lithologies and flow regimes.

Intracratonic basins contain carrier beds and overlying capillary seals that are laterally extensive and nearly horizontal (BETHKE and MARSHAK, 1990). Thus oil migration from the interior of the Illinois basin through Silurian-Devonian strata was essentially lateral and updip (Fig. 16). On the other 


\begin{tabular}{|c|c|c|c|c|c|}
\hline \multicolumn{6}{|c|}{$\begin{array}{l}\text { Table 6. Chemical }(\mathrm{mg} / \mathrm{L}) \text { and } \mathrm{B} \text { isotopic analyses of formation-water samples } \\
\text { (Silurian/Devonian data, except } \delta^{11} \mathrm{~B} \text {, from Stueber and Walter, 1991) }\end{array}$} \\
\hline Sample & $\delta^{11} \mathrm{~B}$ & B & ${ }^{87} \mathrm{Sr} /{ }^{86} \mathrm{Sr}$ & BI & c] \\
\hline \multirow[t]{2}{*}{ SEAWATER } & 39 & 4.53 & & 68.8 & 19798 \\
\hline & \multicolumn{3}{|c|}{ PENNSYLVANIAN } & & \\
\hline 181 & 30 & 0.74 & 0.71052 & 90.5 & 54300 \\
\hline 189 & 23 & 0.81 & 0.71051 & 96.6 & 55560 \\
\hline 208 & 26 & 2.11 & 0.70931 & 53.0 & 16630 \\
\hline 209 & 29 & 1.61 & 0.70936 & 67.8 & 20110 \\
\hline 212 & 27 & 1.44 & 0.70960 & 52.3 & 28730 \\
\hline \multirow[t]{2}{*}{214} & 37 & 2.15 & 0.70965 & 46.1 & 26350 \\
\hline & \multicolumn{3}{|c|}{ MISSISSIPPIAN } & & \\
\hline 139 & 35 & 2.22 & 0.70911 & 77.0 & 23670 \\
\hline 140 & 27 & 2.28 & 0.70966 & 136 & 65370 \\
\hline 146 & 35 & 2.48 & 0.71041 & 138 & 63650 \\
\hline 185 & 30 & 2.36 & 0.70938 & 114 & 39300 \\
\hline 148 & 32 & 3.64 & 0.70945 & 143 & 64650 \\
\hline 150 & 33 & 3.68 & 0.70929 & 186 & 76440 \\
\hline 163 & 30 & 3.12 & 0.70950 & 175 & 74780 \\
\hline 164 & 28 & 2.27 & 0.70976 & 180 & 83740 \\
\hline 143 & 32 & 2.83 & 0.70954 & 197 & 84550 \\
\hline 156 & 39 & 4.89 & 0.70908 & 218 & 78750 \\
\hline 157 & 39 & 3.52 & 0.70971 & 215 & 67180 \\
\hline 167 & 32 & 8.26 & 0.70900 & 227 & 71280 \\
\hline 168 & 34 & 4.75 & 0.70988 & 211 & 73050 \\
\hline 178 & 33 & 4.22 & 0.70939 & 182 & 78330 \\
\hline 126 & 34 & 3.68 & 0.70890 & 143 & 69360 \\
\hline 134 & 37 & 0.25 & 0.70820 & 170 & 83090 \\
\hline 169 & 35 & 9.57 & 0.70820 & 229 & 73190 \\
\hline 194 & 32 & 4.66 & 0.70900 & 167 & 78470 \\
\hline 202 & 32 & 6.91 & 0.70782 & $i 68$ & 73660 \\
\hline \multirow[t]{2}{*}{204} & 35 & 5.39 & 0.70809 & 160 & 71140 \\
\hline & \multicolumn{3}{|c|}{ SILURIAN/DEVONIAN } & & \\
\hline 49 & 22 & 9.35 & 0.70981 & 232 & 71370 \\
\hline 54 & 20 & 10.3 & 0.70964 & 235 & 70580 \\
\hline 79 & 24 & 4.60 & 0.71004 & 274 & 83350 \\
\hline 122 & 28 & 5.05 & 0.71026 & 273 & 82340 \\
\hline 153 & 19 & 13.0 & 0.70955 & 215 & 58010 \\
\hline 256 & 18 & 11.3 & 0.70958 & 255 & 75200 \\
\hline 262 & 24 & 8.96 & 0.70948 & 230 & 75300 \\
\hline
\end{tabular}

hand, because New Albany shales have been identified as the source of petroleum in Mississippian and Pennsylvanian reservoir rocks (HATCH et al., 1991), oil migration above the New Albany was cross-formational with a significant vertical component.

Long-range migration of formation waters in the Illinois basin was proposed by BETHKE (1986) in order to explain the deposition of ores in the Upper Mississippi Valley district. He used numerical modeling techniques to suggest that uplift of the Pascola arch, which exposed basal Cambrian and Ordovician aquifers at its crest, could have initiated gravitydriven flow at rates of a few meters per year northward across the basin thereby transporting warm brines to the basin's northern margin. BETHKE et al. (1991) also used this Mesozoic period of regional groundwater flow to explain the geochemical correlation of oils from outlying Silurian carbonate reservoirs in central Illinois with New Albany Group source rocks in the southeastern portion of the state. They pointed out that the force driving migration of an immiscible oil phase consists of component forces representing the effects of basin hydrodynamics, buoyancy, and capillary effects. They determined that the hydrodynamic groundwater drive for migration was comparable to the component of buoyant drive acting along the nearly horizontal migration pathways; it facilitated migration by sweeping oil past irregularities in the dips of carrier beds. Furthermore, oil generation in New Albany shales mostly occurred between 300 and $150 \mathrm{Ma}$ (CLUFF and BYRNES, 1991), within the time interval of the proposed northward groundwater flow regime.

Geochemical characteristics of formation waters from Silurian-Devonian strata are consistent with evolution under the paleohydrologic flow regime described above, provided that residual evaporite brines in the strata were not completely replaced by meteoric water. Chloride-bromide relations (Fig. $3 \mathrm{~b}$ ), which indicate that salinity was acquired through subaerial seawater evaporation modified by meteoric water dilution (STUEBER and WALTER, 1991), require isolation of these waters from those in overlying Mississippian-Pennsyl- 


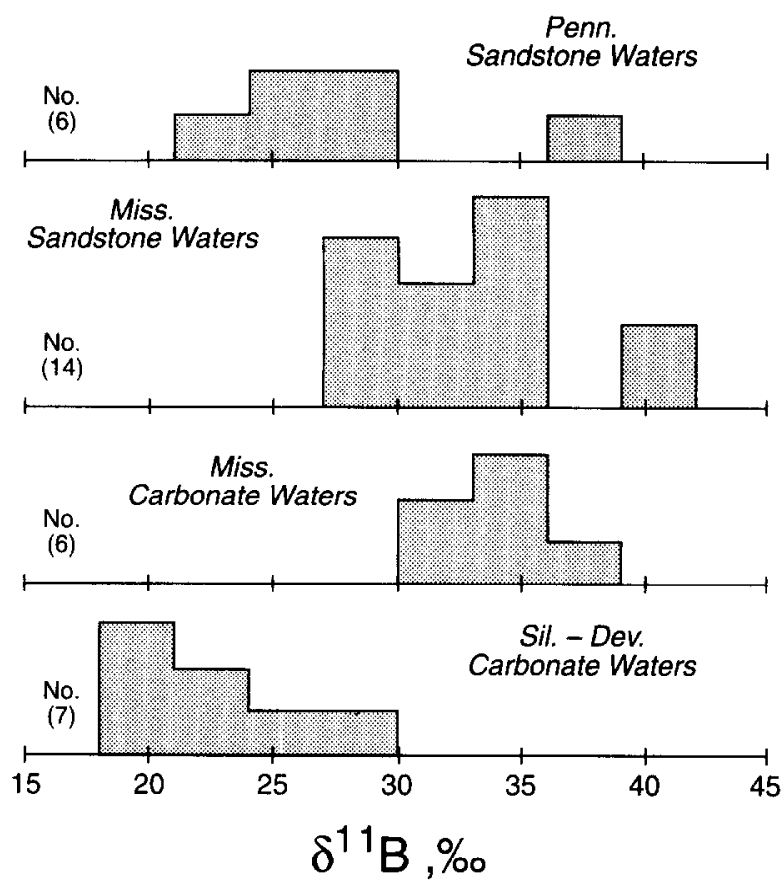

FIG. 14. Distribution of $\delta^{11} \mathrm{~B}$ in formation waters from the Illinois basin.

vanian reservoirs where brine salinity was augmented by halite dissolution (Fig. 3a). Correlation between ${ }^{87} \mathrm{Sr} /{ }^{86} \mathrm{Sr}$ and $1 /$ $\mathrm{Sr}$ in Silurian-Devonian waters (Fig. 10a) has been interpreted by STUEBER et al. (1987) and by STUEBER and WALTER (1991) as a two-component mixing relation among waters from a single hydrogeologic system that evolved when ${ }^{87} \mathrm{Sr}$ enriched water and petroleum from New Albany shales entered Silurian-Devonian carbonate rocks and mixed with interstitial water containing marine Sr. As the ${ }^{87} \mathrm{Sr}$-enriched water migrated updip through the carbonate rocks under gravity-driven flow, it was mixed in different proportions with interstitial formation water until becoming isolated in structural and stratigraphic traps (Fig. 16). Extensive lateral flow in a sequence of carbonate rocks apparently permitted the establishment and preservation of the $\mathrm{Sr}$ isotopic record of two-component mixing. BETHKE et al. (1991) expressed the opinion that Silurian and Devonian carbonates immediately underlying a widespread unconformity at the base of the New Albany Group carried much of the migrating oil to the outlying reservoirs in central Illinois. The Ordovician Maquoketa Shale Group (Fig. 16), which also forms a regional aquitard (BETHKE et al., 1991), overlies carbonate petroleum reservoirs of the Galena Group. Limited $\mathrm{Cl}-\mathrm{Br}$ and strontium isotope analyses of formation waters from these reservoirs (WALTER et al., 1990; STUEBER et al., 1987) suggest that the waters have cvolved gcochemically in much the same way as the Silurian-Devonian brines.

Formation waters from Mississippian-Pennsylvanian strata show geochemical characteristics indicative of cross-formational fluid flow. These brines are marked by $\mathrm{Cl} / \mathrm{Br}$ ratios that have been elevated through halite dissolution (Fig. 3a); elevated $\mathrm{Cl} / \mathrm{Br}$ ratios are found in waters from every sampled stratigraphic unit above the apparent halite source, the evap- orite zone in the lower St. I ouis Limestone (Fig. 2). This geochemical evidence can only be explained by extensive upward migration of formation waters (Fig. 16).

BETHKE et al. (1991) used computer simulation techniques to model compaction-driven groundwater flow as the Illinois basin subsided and filled with sediments during the Paleozoic. Although the modeling results show a flow system characterized by fluid velocities of only a few millimeters per year, it is likely that the upward, cross-formational migration of Mississippian-Pennsylvanian formation waters occurred within this Paleozoic compaction-driven flow regime. Because oil generation took place after sediments had been compacted and the basin was under the influence of Mesozoic gravitydriven flow (BETHKE et al., 1991), upward migration of New Albany-generated oil into Mississippian and Pennsylvanian reservoirs must have been driven primarily by buoyant forces (Fig. 16). Thus, ${ }^{87} \mathrm{Sr}$-enriched formation water from New Albany shales was probably not associated with this petroleum migration, consistent with our interpretation that water-rock interactions are responsible for elevated ${ }^{87} \mathrm{Sr} /{ }^{86} \mathrm{Sr}$ ratios in Mississippian and Pennsylvanian brines. However, upward movement of a ${ }^{87} \mathrm{Sr}$-enriched fluid from the New Albany during Paleozoic compaction-driven flow could have taken place.

The distinct geochemical fluid regimes found in SilurianDevonian and Mississippian-Pennsylvanian strata appear to have evolved independently as a result of their isolation by
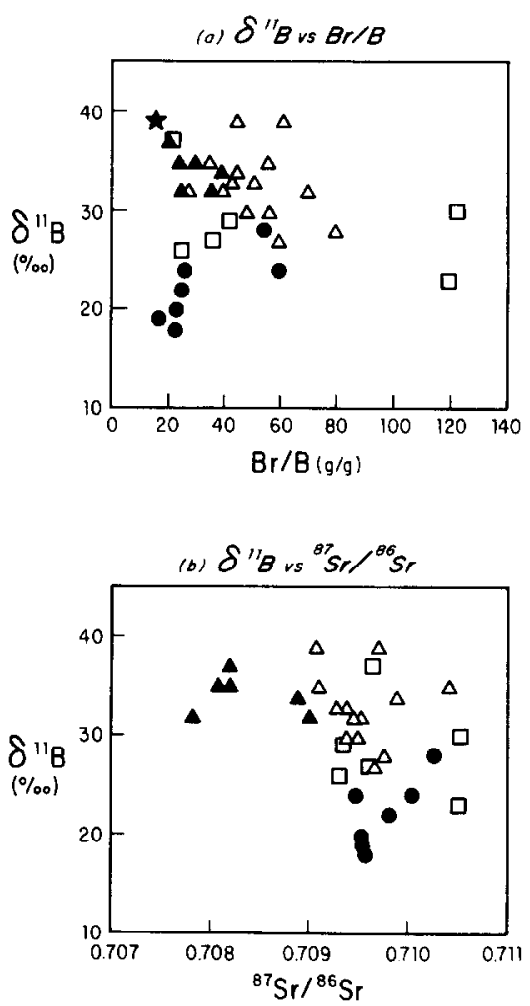

FiG. 15. (a) $\delta^{11} \mathrm{~B}$ vs. $\mathrm{Br} / \mathrm{B}$, and (b) $\delta^{11} \mathrm{~B}$ vs. ${ }^{87} \mathrm{Sr} /{ }^{86} \mathrm{Sr}$ in formationwater samples from Silurian/Devonian, Mississippian and Pennsylvanian reservoirs in the Illinois basin. (๑), Silurian/Devonian carbonate waters; ( $\Delta$ ), Mississippian carbonate waters; $(\Delta)$, Mississippian sandstone waters; $(\square)$, Pennsylvanian sandstone waters; $(\star)$, modern seawater. 


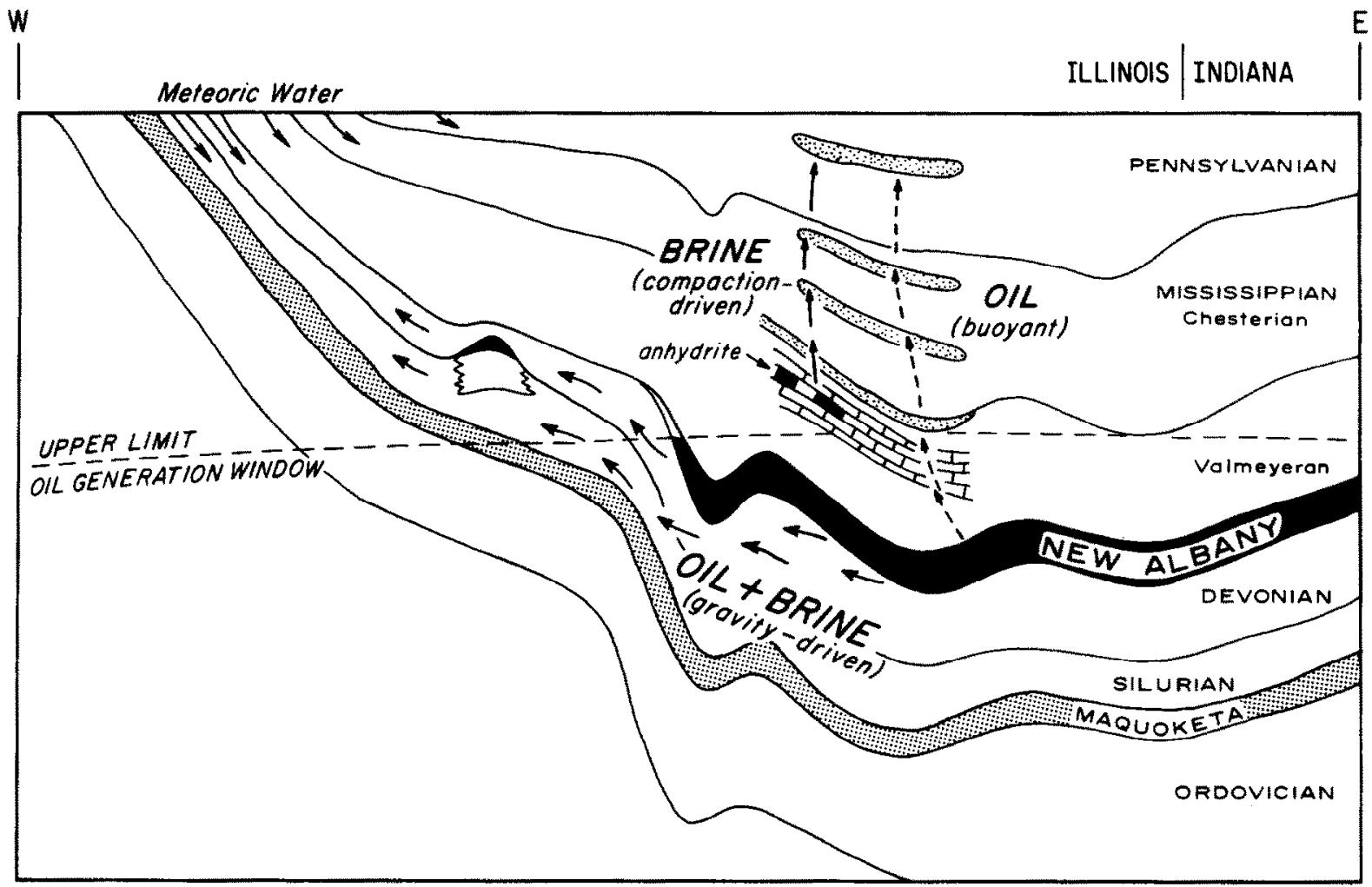

FIG. 16. Schematic east-west subsurface cross-section of the Illinois basin, showing fluid flow patterns that are consistent with geochemical data presented here and by STUEBER and WALTER (1991) and HATCH et al. (1991) and with the paleohydrologic flow regimes of BETHKE et al. (1991). After BARRows and CLUFF (1984).

the New Albany regional aquitard. Development of different geochemical characteristics in the formation waters was apparently controlled by a combination of the lithologic makeup of the two segments of the stratigraphic section and the effects of the different flow regimes that existed in the Illinois basin during the Paleozoic and Mesozoic. Characteristics of the two fluid regimes are summarized in Table 7.

\section{CONCLUSIONS}

Formation waters from Mississippian and Pennsylvanian strata in the Illinois basin probably achieved their initial salinity through subaerial evaporation of seawater short of halite saturation in a tropical, restricted shallow marine environment. In the subsurface, brine compositions were modified through water-rock interactions: $\mathbf{K}$ depletion through interaction with clay minerals, $\mathrm{Ca}$ enrichment and $\mathrm{Mg}$ depletion as a result of dolomitization of limestones, and Sr enrichment by $\mathrm{CaCO}_{3}$ recrystallization and dolomitization. Most notably, $\mathrm{Na}$ and $\mathrm{Cl}$ were significantly enriched through dissolution of halite, probably from an evaporite zone in the St. Louis Limestone. These brines have been extensively diluted by mixing with meteoric waters, possibly during development of the pre-Pennsylvanian unconformity as well as during subsequent intervals of subaerial reservoir-rock exposure. Thus, Mississippian-Pennsylvanian formation waters and those from Silurian-Devonian strata had a very similar origin and diagenetic evolution except in one important aspect. Halite dissolution has marked Mississippian-Pennsylvanian wa- ters with elevated $\mathrm{Cl} / \mathrm{Br}$ ratios, whereas Silurian-Devonian brines have retained the $\mathrm{Cl} / \mathrm{Br}$ ratio of seawater.

Strontium isotope ratios range from coeval seawater values in some Ste. Genevieve Limestone waters through considerably more radiogenic ratios in waters from siliciclastic reservoirs. Various lines of evidence suggest that the radiogenic ${ }^{87} \mathrm{Sr}$ was probably acquired through water-rock interactions with siliciclastic minerals in Mississippian-Pennsylvanian strata. These formation waters show completely unsystematic relations between ${ }^{87} \mathrm{Sr} /{ }^{86} \mathrm{Sr}$ and $1 / \mathrm{Sr}$; the present $\mathrm{Sr}$ concentration levels in Ste. Genevieve and Aux Vases brines are controlled by equilibration with celestite, which would obscure any two-component mixing relations that may have once been present. Thus, the strontium isotope systematics of these formation waters contrast with those of SilurianDevonian brines, which show a two-component mixing relationship and undersaturation with respect to celestite. This represents a second important geochemical distinction between the fluids in these two major segments of the stratigraphic section.

Elevated $\mathrm{Cl} / \mathrm{Br}$ ratios in waters from Mississippian-Pennsylvanian reservoirs above the St. Louis Limestone indicate extensive upward, cross-formational brine migration that probably took place under a compaction-driven flow regime within the Illinois basin during the Paleozoic. Geochemical characteristics of Silurian-Devonian brines are consistent with evolution under a gravity-driven flow regime that presumably prevailed in the basin during the Mesozoic. Thus, the evolution of the two geochemical formation-water regimes has 
Table 7. Characteristics of two distinct fluid regimes, separated by the New Albany Shale Group

\begin{tabular}{|ccc|}
\hline MIGRATION & $\begin{array}{c}\text { SILURIAN-DEVONIAN } \\
\text { FORMATION WATERS }\end{array}$ & $\begin{array}{c}\text { MISS.-PENN. } \\
\text { FORMATION WATERS }\end{array}$ \\
SALINITY & lateral, updip & $\begin{array}{c}\text { cross-formational, } \\
\text { vertical component }\end{array}$ \\
& $\begin{array}{c}\text { subaerial evaporation } \\
\text { of seawater }\end{array}$ & $\begin{array}{c}\text { evaporation followed } \\
\text { by halite dissolution }\end{array}$ \\
${ }^{87} \mathrm{Sr} /{ }^{86} \mathrm{Sr}$ EVOLUTION & fluid mixing & water-rock interaction \\
$\mathrm{Sr}$ CONCENTRATION & fluid mixing, & water-rock interaction, \\
& local precipitation effects & celestite equilibration
\end{tabular}

been significantly influenced by paleohydrologic flow systems, and their geochemical distinction has been maintained by the intervening New Albany Shale Group regional aquitard.

\begin{abstract}
Acknowledgments-Acknowledgment is made to the donors of the Petroleum Research Fund, administrated by the American Chemical Society, for partial support of this research under Grants PRF-20576B2 (AMS) and PRF-18640-AC2 (LMW). Additional support was provided by NSF Grant EAR-8657180 (LMW) and by Chevron Oil Field Research Company. We are grateful to L. S. Land for generously providing data on the boron isotopic composition of Illinois basin formation waters. Mass spectrometric Sr analyses at Argonne National Laboratory were made possible through the Division of Educational Programs; technical assistance furnished by E. G. Rauh of the Chemical Technology Division is appreciated. Core samples of New Albany shales were obtained from the Illinois State Geological Survey with the cooperation of C. J. Zelinsky; we acknowledge the considerable additional assistance provided by members of the Oil and Gas Section. Discussions with A. B. Carpenter and F. C. Furman were extremely beneficial. We appreciate valuable comments from $L$. S. Land on an earlier version of this manuscript and the very helpful reviews of H. J. Abercrombie and F. J. Longstaffe. We thank B. Stueber for preparing the figures, $\mathbf{J}$. Miller for typing the manuscript, and $\mathbf{R}$. Gibson for assistance in preparing the tables.
\end{abstract}

\section{Editorial handling: R. J. Spencer}

\section{REFERENCES}

BarRows M. H. and Cluff R. M. (1984) New Albany Shale Group (Devonian-Mississippian) source rocks and hydrocarbon generation in the Illinois basin. In Petroleum Geochemistry and Basin Evaluation (ed. G. Demaison and R. J. MURris); Amer. Assoc. Petrol. Geol. Mem. 35, pp. 111-138.

BETHKE C. M. (1986) Hydrologic constraints on the genesis of the Upper Mississippi Valley mineral district from Illinois basin brines. Econ. Geol. 81, 233-249.

BeTHKe C. M. and MarshaK S. (1990) Brine migrations across North America: The plate tectonics of groundwater. Ann. Rev. Earth Planet. Sci. 18, 287-315.

BethKe C. M., ReED J. D., and Oltz D. F. (1991) Long-range petroleum migration in the Illinois basin. In Interior Cratonic Basins (ed. M. W. Leighton, et al.); Amer. Assoc. Petrol. Geol. Mem. 51, pp. 455-472.

BRAND U. ( 1991) Strontium isotope diagenesis of biogenic aragonite and low-Mg calcite. Geochim. Cosmochim. Acta 55, 505-513.

Burke W. H., Denison R. E., HFtherington E. A., Koepnick R. B., NELSON H. F., and OTTO J. B. (1982) Variation of seawater ${ }^{87} \mathrm{Sr} /{ }^{86} \mathrm{Sr}$ throughout Phanerozoic time. Geology 10, 516-519.
CARPENTER A. B. (1978) Origin and chemical evolution of brines in sedimentary basins. Oklahoma Geol. Survey Circ. 79, 60-77.

ClufF R. M. and BYRNeS A. P. (1991) Lopatin analysis of maturation and petroleum generation in the Illinois basin. In Interior Cratonic Basins (ed. M. W. Leighton, et al.); Amer. Assoc. Petrol. Geol. Mem. 51, pp. 425-454.

CluFF R. M. and LINEBACK J. A. (1981) Middle Mississippian carbonates of the Illinois basin. Illinois Geol. Soc. and Illinois State Geol. Surv. Joint Publication.

Collins A. G. (1975) Geochemistry of Oilfield Waters. Elsevier.

FAure G. (1986) Principles of Isotope Geology, 2d ed. J. Wiley \& Sons.

GraF D. L., MeEnTS W. F., FriedMan I., and ShIMP N. F. (1966) The origin of saline formation waters. III. Calcium chloride water. Illinois State Geol. Surv. Circ. 397.

HANOR J. S. (1979) The sedimentary genesis of hydrothermal fluids. In Geochemistry of Hydrothermal Ore Deposits (ed. H. L. BARNES), pp. 137-168. J. Wiley \& Sons.

HANOR J. S. (1987) Origin and Migration of Subsurface Sedimentary Brines. Soc. Econ. Paleon. Mineral, Short Course 21.

HARDER H. (1974) Boron abundance in common sediments and sedimentary rock types. In Handbook of Geochemistry (ed. K. H. WEDEPOHL), pp. 5-K-1-5-K-13. Springer-Verlag.

HATCH J. R., RISATTI J. B., and KING J. D. (1991) Geochemistry of Illinois basin oils and hydrocarbon source rocks. In Interior Cratonic Basins (ed. M. W. Leighton, et al.); Amer. Assoc. Petrol. Geol. Mem. 51, pp. 403-423.

HEIER K. S. and BILLINGS G. K. (1969) Lithium abundance in common sediments and sedimentary rock types. In Handbook of Geochemistry (ed. K. H. WEDEPOHL), pp. 3-K-1-3-K-3. SpringerVerlag.

HiRNer A. V., KRITSOTAKIS K., and Tobschall H. J. (1990) Metalorganic associations in sediments. I. Comparison of unpolluted recent and ancient sediments and sediments affected by anthropogenic pollution. Appl. Geochem. 5, 491-505.

HOLSER W. (1979) Trace elements and isotopes in evaporites. In Marine Minerals (ed. R. G. BURNS), Rev. Mineral. 6, pp. 295346.

Kharaka Y., Gunter W. D., AgGarwal P. K., Perkins E. H., and DEBRAAL J. D. (1988) SOLMINEQ.88: A computer program for geochemical modeling of water-rock interactions. U.S. Geol. Surv. Water Resources Investigations Rept. 88-4227.

KolatA D. R. and NeLSON W. J. (1991) Tectonic history of the Illinois basin. In Interior Cratonic Basins (ed. M. W. LEIGHTON, et al.), Amer. Assoc. Petrol. Geol. Mem. 51, pp. 263-285.

KRUMBEIN W. C. (1951) Occurrence and lithologic associations of evaporites in the United States. J. Sediment. Petrol. 21, 63-81.

LAND L. S. and PrezBindowski D. R. (1981) The origin and evolution of saline formation water, Lover Cretaceous carbonates, south-central Texas, U.S.A. J. Hydrol. 54, 51-74. 
LEIGHTON M. W. (1991) Introduction to interior cratonic basins. In Interior Cratonic Basins (ed. M. W. LEIGHTON, et al.), Amer. Assoc. Petrol. Geol. Mem. 51, pp. 1-24.

MACPHERSON G. L. and LAND L. S. (1989) Boron in saline brines, Gulf of Mexico Sedimentary Basin, USA. 6th Inter. Symposium, Water-Rock Interactions, Malvern, France.

MCGRAIN P. and HELTON W. L. (1964) Gypsum and anhydrite in the St. Louis Limestone in northwestern Kentucky. Kentucky Geol. Surv. Inf. Circ. 13.

MCGREGOR D. J. ( 1954 ) Gypsum and anhydrite deposits in southwestern Indiana. Indiana Geol. Survey Prog. Rept. No. 8.

Meents W. F., Bell A. H., Rees O. W., and Tilbury W. G. (1952) Illinois oil-field brines, their geological occurrence and chemical composition. Illinois State Geol. Surv., Illinois Petrol. 66.

Moldovanyi E. P. and WalTeR L. M. (1992) Regional trends in water chemistry, Smackover Formation, southwest Arkansas: Geochemical and physical controls. Bull. Amer. Assoc. Petrol. Geol. 76, 864-894.

NESBITT H. W. (1980) Characterization of mineral-solution interactions in Carboniferous sandstones and shales of the Illinois sedimentary basin. Amer. I. Sci. 280, 607-630.

NESBITT H. W. (1985) A chemical equilibrium model for the Illinois basin formation waters. Amer. J. Sci. 285, 436-458.

Popp B. N., Podosek F. A., Brannon J. C., ANDFrson T. F., and PIER J. ( 1986$){ }^{87} \mathrm{Sr} /{ }^{86} \mathrm{Sr}$ ratios in Permo-Carboniferous sea water from the analyses of well-preserved brachiopod shells. Geochim. Cosmochim. Acta 50, 1321-1328.

PotTer P. E. (1962) Late Mississippian sandstones of Illinois. Illinois State Geol. Surv. Circ. 340

Potter P. E. and Glass H. D. (1958) Petrology and sedimentation of the Pennsylvanian sediments in southern Illinois: A vertical profile. Illinois State Geol. Surv. Rept. Inv. 204.

RILEY J. P. and CHESTER R. (1971) Introduction to Marine Chemistry. Academic Press.

SAXBY D. E. and LAMAR J. E. (1957) Gypsum and anhydrite in Illinois. Illinois State Geol. Surv. Circ. 226.

SCHWarCZ H. P., AGyei E. K., and MCMullen C. C. (1969) Boron isotopic fractionation during adsorption from seawater. Earth Hlanet. Sici. Lett. 6, 1-5.

Scotese C. R., Bambach R. K., Barton C., Van Der Voo R., and ZEIGLER A. M. (1979) Paleozoic base maps. J. Geol. 87, 217 277.
SEYFRIFD W. F., JANECKY D. R., and MoTTL M. J. (1984) Alteration of the oceanic crust: Implications for geochemical cycles of lithium and boron. Geochim. Cosmochim. Acta 48, 557-569.

Spivack A. J., PALMer M. R., and EdMOND J. M. (1987) The sedimentary cycle of the boron isotopes. Geochim. Cosmochim. Acta 51, 1939-1949.

StOessell R. K. and CARPENTER A. B. (1986) Stoichiometric saturation tests of $\mathrm{NaCl}_{1-\mathrm{x}} \mathrm{Br}_{\mathrm{x}}$ and $\mathrm{KCl}_{1-\mathrm{x}} \mathrm{Br}_{\mathrm{x}}$. Geochim. Cosmochim Acta 50, 1465-1474.

Stoffyn-Egli P. and Mackenzie F. T. (1984) Mass balance of dissolved lithium in the oceans. Geochim. Cosmochim. Acta 48, $859-872$.

Stueber A. M. and WAlter L. M. (1991) Origin and chemical evolution of formation waters from Silurian-Devonian strata in the Illinois basin, USA. Geochim. Cosmochim. Acta 55, 309-325.

Stueber A. M., Pushk ar P., and Hetherington E. A. (1987) A strontium isotopic study of formation waters from the Illinois basin, U.S.A. Appl. Geochem. 2, 477-494.

SWANN D. H. (1963) Classification of Genevievian and Chesterian (Late Mississippian) rocks of Illinois. Illinois State Geol. Surv. Rept. Inv. 216.

SWANN D. H. (1967) A summary geological history of the Illinois basin. In Geology and Petroleum Production of the Illinois Basin, pp. 3-21. Illinois Geol. Soc.

TREWORGY J. D. (1991) Kaskaskia sequence: Mississippian Valmeyeran and Chesterian Series. In Interior Cratonic Basins (ed. M. W. Leighton, et al.), Amer. Assoc. Petrol. Geol. Mem. 51, pp. $125-142$.

TREWORGY J. D. and DEVERA J. A. (1991) Kaskaskia sequence overview: Middle Devonian Series through Chesterian Series. In Interior Cratonic Basins (ed. M. W. LEIGHTON, et al.), Amer. Assoc. Petrol. Geol. Mem. 51, pp. 109-112.

Vengosh A., SIARINSKY A., Kolodny Y., and ChIVAS A. R. (1991a) Boron isotope geochemistry as a tracer for the evolution of brines and associated hot springs from the Dead Sea, Israel. Geochim. Cosmochim. Acta 55, 1689-1695.

Vengosh A., Chivas A. R., MCCulloch M. T., Starinsky A. and KolodNY Y. (1991b) Boron isotope geochemistry of Australian salt lakes. Geochim. Cosmochim. Acta 55, 2591-2606.

Walter L. M., Stueber A. M., and Huston T. J. (1990) Br-Cl$\mathrm{Na}$ systematics in Illinois basin fluids: Constraints on fluid origin and evolution. Geology 18, 315-318. 